\title{
JONES 7. WOLF: GHURCH AUTONOMY AND THE RELIGION CLAUSES OF THE FIRST AMENDMENT
}

\section{Arlin M. Adams $\dagger$ and Willtam R. Hanlon +}

From time to time, churches, no less than other voluntary associations, experience differences in their internal affairs that may lead to factionalism and division. Whatever the sources of friction, members of church groups who cannot achieve harmony among themselves must look to the courts for ultimate resolution of their disputes. ${ }^{1}$ Church controversies that are perceived to involve purely ecclesiastical matters ordinarily are dismissed by civil courts as beyond their competence, without inquiry into the merits. ${ }^{2}$ Yet, most religious altercations that culminate in litigation are at least indirectly about the use, possession, and control of church property. In view of the obvious and legitimate state interest in the peaceful resolution of property disputes, civil courts have little choice but to assume jurisdiction in such cases, notwithstanding the fact that the conflicts involve a church. ${ }^{3}$ The resolution of church disputes, however, evokes concerns not present in other types of adjudica. tion. For inquiry into the permissible forms and limits of judicial intervention when the matters in controversy relate to disagreements over religious doctrine and practice embraces more funda-

f Circuit Judge, United States Court of Appeals for the Third Circuit. B.S. 1941, M.A. 1950, Temple University; J.D. 1947, University of Pennsylvania.

tf Law Clerk to Judge Adams. B.A. 1975, College of William and Mary; B.A. 1977, Oxford University; J.D. 1979, University of Pennsylvania.

The authors gratefully acknowledge the assistance of Brian E. Gray and Kim J. Landsman.

I One student of this subject estimated in 1962 that approximately 25 churchproperty disputes are heard by civil courts annually. Note, Judicial Intervention in Disputes Over the Use of Church Property, 75 Hanv. L. Rev. 1142, 1142 n.3 (1962) [hereinafter cited as HaRv. Note]. Another student has counted roughly 10 reported decisions per year from the federal courts and highest state courts. Note, Judicial Intervention in Church Property Disputes-Some Constitutional Considerations, 74 YALE L.J. 1113, 1113 n.I (1965) [hereinafter cited as Yare Note].

2 See, e.g., Watson v. Garvin, 54 Mo. 353, 378 (1873); accord, Schwartz v. Jacobs, 352 S.W.2d 389 (Mo. App. 1961); Kompier v. Thegza, 213 Ind. 542, 13 N.E.2d 229 (1938).

3 See, e.g., Presbyterian Church v. Mary Elizabeth Blue Full Memorial Presbyterian Church, 393 U.S. 440, 445 (1969) ("[T]he State has a legitimate interest in resolving property disputes, and . . a civil court is a proper forum for that resolution."). 
mental issues concerning the protections afforded by the first amendment.

Standards governing judicial resolution of church-property disputes have emerged over time through a sporadic process of caseby-case adjudication. In 1871, the Supreme Court in Watson $v$. Jones $^{*}$ enunciated as a matter of federal common law a broad doctrine of judicial deference to the internal decisionmaking unit of a church, based upon the church's established "polity." ' The body of decisional law that developed in regard to church-property disputes since that early adjudication thus reflects not only its common law origin, but also the polity of the church groups concerned. In particular, most civil courts distinguished only two broad forms of church organization-the congregational and the hierarchical. ${ }^{6}$ In the case of a congregational church, resolution

480 U.S. (13 Wall.) 679 (1871).

5 The question of "polity" is often the focus of church-property disputes. It refers to the particular system of church government upon which church members have agreed, including the structural allocation of authority within the church and the established grievance procedures for resolving internal disputes. For general discussions of the nature and forms of church polity, see J. SCHAvEr, THE PoLrTY of the Churceres (1947); W. Sperry, Religion in America (1946); Hary. Note, supra note 1.

${ }^{6}$ Although courts generally have distinguished only between the hierarchical and the congregational forms of church polity, an examination of the estimated 256 denominations and sects identified with the approximately 333,000 local churches in the United States reveals three general types of church organizations.

A hierarchical organization has been defined by the Supreme Court as a general organization of churches "having similar faith and doctrine with a common ruling convocation or ecclesiastical head." Kedroff v. Saint Nicholas Cathedral, 344 U.S. 94, 110 (1952). At least two distinct types of hierarchical polity may be discerned, however. Under the episcopal form of polity, all authority reposes in certain ecclesiastical officers. In a presbyterial arrangement, authority is delegated instead to an ascending succession of judicatories composed of laymen as well as ministers. Unlike episcopal polities, presbyterial churches are representative, inasmuch as both ruling "elders" and ministers constituting the governing bodies are elected by the congregation. Among the principal denominations with an episcopal form of polity are the Protestant Episcopal Church, the Methodist Church, the Roman Catholic Church, and the Eastern Orthodox Churches. Those churches classified as having a presbyterlal form of polity include the United Presbyterian Church of North America, the Presbyterian Church in the United States, and the Assemblies of God.

In contrast to the hierarchical form of organization, the central characteristic of a congregational polity is the autonomy of each local entity. While congregational churches sometimes affliate with other religious organizations, they generally recognize no superior authority over the local congregation. Subject to the rules prescribed for its own self-government, a congregational church is free to affiliate and withdraw from other church organizations at will. Examples of a congregational polity are provided by the numerous Baptist bodies, the Jewish congregations, the Church of Christ, and the Quakers.

Although the polities of most denominations may be characterized as either episcopal, presbyterial, or congregational, such classifications are merely approximations drawn from the most typical of a great variety of organizational patterns among religious associations, many of which differ in significant respects from the standard forms of government and some of which defy classification altogether. See generally W. SpERrY, supra note 5 , at 283-84. 
of the dispute was determined according to the rules governing ordinary voluntary associations. Courts generally deferred to a determination reached by officers vested with control of the property; in the absence of clear title, the decision reached by a majority of the congregation was held to be conclusive. If the polity of the church was hierarchical, however, courts deferred instead to the solution provided by the highest church tribunal of the central organization that had addressed the conflict. This approach rendered resolution of church-property disputes conceptually simple; indeed, in many cases ascertainment of the church's polity became the determinative inquiry.

The doctrine of judicial deference enunciated in Watson was grounded in a general reluctance to interfere with the internal affairs of private associations. At least in part, it rested on the belief that religious societies should be treated equally with other voluntary associations. ${ }^{7}$ Judicial reluctance to intrude in the affairs of religious associations also was influenced to some extent by a self-perceived lack of competence in matters of religious doctrine and practice. ${ }^{8}$ Quite apart from its roots in associational freedom and institutional competence, however, the doctrine of deference represented an attempt on the part of the judiciary to further the basic ideals of religious liberty and autonomy through the separation of church and state. ${ }^{\circ}$ Although not a constitutional decision, 10 the "rule of action" set forth in Watson was said to be "founded in a broad and sound view of the relations of church and state under our system of laws." 11

7 See notes $42-48$ infra \& accompanying text.

8 To allow civil-court review of church decisions, the Supreme Court stated in Watson, would in effect permit an appeal "from the more learned tribunal in the law which should decide the case, to the one which is less so." 80 U.S. (13 Wall.) at 729. See notes 193-94 infra \& accompanying text.

980 U.S. (13 Wall.) at 729. See L. Tribe, Amerucan Constrututional LaW $\$ 14-12$, at 877 (1978) ("[T]he doctrine represents a recognition of the[ ] necessary separation [of religious bodies] from governmental entanglement, a separation designed as much to protect the state as to defend the church."); Kauper, Church Autonomy and the First Amendment: The Presbyterian Church Case, 1969 Sur. Cr. Rev. 347, 353; Note, The Role of Civil Courts in Church Disputes, 1977 Wis. L. Rev. 904, 910 [hereinafter cited as Wis. Note].

10 Inasmuch as Watson was decided prior to Erie Ry. Co. v. Tompkins, 304 U.S. 64 (1938), the federal courts were still applying federal common law on the basis of Swift v. Tyson, 41 U.S. (16 Pet.) I (1842). Moreover, the religion clauses of the first amendment had not yet been applied to the states. The first decisions to do so were Cantwell v. Connecticut, 310 U.S. 296 (1940) (free exercise), and Everson v. Board of Education, 330 U.S. I (1947) (establishment).

1180 U.S. (13 Wall.) at 727, quoted in Kedroff v. Saint Nicholas Cathedral, 344 U.S. 94,113 (1952). 
In the apparent belief that a "wall of separation" between church and state was necessary to maintain those relations, Watson sought to promote "a spirit of freedom for religious organizations" by respecting their right to decide for themselves matters of internal concern, free from state interference. ${ }^{12}$ As a means of maintaining this separation, Watson attempted to avoid judicial involvement in doctrinal clashes by assuming that all members of hierarchical organizations implicitly submit themselves to the decisionmaking authority of the church in ecclesiastical and property matters. ${ }^{13}$ Judicial willingness to defer to the determinations of hierarchicalchurch tribunals thus afforded hierarchical associations great autonomy in conducting their affairs. Although subsequent opinions exhibited concern in this regard and suggested exceptions to the nonintervention doctrine in cases of "fraud, collusion or arbitrariness," 14 the principle of judicial deference in the main retained its vitality. After the limitations of the first amendment became applicable to the states, ${ }^{15}$ the Supreme Court reaffirmed the deference principle and implied that it had constitutional status under the free exercise clause. ${ }^{16}$

If the rival parties to a dispute over church property are at least agreed that power to prescribe use of the property has been delegated to a body within the hierarchy of the church, application of the deference doctrine operates reasonably well. The major difficulties occasioned by this approach, once the hierarchical association has been ascertained, ${ }^{17}$ are the identification of the authoritative decisionmaking body within the hierarchy and the determination of what that body has decided.18 When the fundamental point of contention is which of two competing local factions in fact possesses authority over the contested property, however, unbounded deference to a hierarchical body's determination of that question poses serious problems. In this situation, judicial reluctance to evaluate the merits of the litigants' respective claims not only appears to deprive local church groups of the same protection afforded

12 Kedroff v. Saint Nicholas Cathedral, 344 U.S. 94, 116 (1952).

13 See notes 50-52 infra \& accompanying text.

14 See notes 53-61 infra \& accompanying text.

15 See note 10 supra.

${ }^{16}$ Kreshik v. Saint Nicholas Cathedral, 363 U.S. 190 (1960); Kedroff v. Saint Nicholas Cathedral, 344 U.S. 94 (1952).

17 Watson 0 . Jones offered no criteria for making the crucial and often difficult decision whether the denomination in question is congregational or hierarchical. See HARv. Note, supra note 1 , at 1153-60. As we shall discuss, judicial determination of church polity itself raises concerns involving the religion clauses of the first amendment. See notes 195-97 infra \& accompanying text.

18 See generally HaRv. Note, supra note 1, at 1158-67. 
members of other voluntary associations, but also raises the presentiment of judicial establishment of religion.

That judicial intervention in church-property disputes implicates the establishment clause as well as the free exercise clause was first recognized by the Supreme Court in 1969. In a persuasive dictum, the Court in Presbyterian Church v. Mary Elizabeth Blue Hull Memorial Presbyterian Church ${ }^{19}$ introduced the concept of "neutral principles of law, developed for use in all property disputes" ${ }^{20}$ with the salutory instruction that such principles "can be applied without 'establishing' churches to which property is awarded." 21 While the Court's opinion neither defined nor elaborated on the meaning of "neutral principles," it indicated that, consistent with the religion clauses of the first amendment, churches could be subject to the same law that governed other voluntary associations-traditional contract, property, and trust law.

The summary invocation of "neutral principles" in Presbyterian Church unsettled a century of doctrinal development and injected considerable confusion into the law concerning the proper application of these principles and the nature of their relation to the role of judicial deference. Judicial deference to a hierarchical organization's decisionmaking organ is not a rule generally applicable to property disputes, except insofar as it may be called "deference" if that body has been able to place legal title where it wants. As a result, commentators read the Court's opinion as both a rejection of the deference doctrine and an indication that henceforth religious groups would be treated on a plane with other voluntary associations. ${ }^{22}$ Given such expectations, the Supreme Court's next major pronouncement eight years later in Serbian Eastern Orthodox Diocese v. Milivojevich ${ }^{23}$ served only to confound commentators further. There, the Court indicated that, in certain circumstances, decisions by authoritative church tribunals concerning issues of internal administration and polity, as well as matters of faith and discipline, bind civil courts. To many, Serbian's holding signaled the demise of the neutral-principles ap. proach to adjudicating disputes involving hierarchical churches. ${ }^{24}$ At the very least, Serbian seemed to circumscribe severely the role of civil courts in intrachurch conflicts.

19393 U.S. 440 (1969).

20 Id. 449.

21 Id.

22 See notes 77-78 supra \& accompanying text.

23426 U.S. 696 ( 1976 ).

24 See notes 88,94 \& 95 infra \& accompanying text. 
Judicial confusion and uncertainty concerning the vitality of neutral principles and the limits of the deference doctrine after Serbian contributed to a series of conflicting decisions and a resulting lack of uniformity among state courts in this area. While some courts believed themselves constitutionally bound to yield in all cases to a hierarchical tribunal's determination, ${ }^{25}$ others thought that the first amendment mandated deference only when a dispute was not susceptible to resolution through neutral principles of law. ${ }^{26}$

Perhaps with a view to these concerns, the Supreme Court in Jones $v$. Wolf, ${ }^{27}$ a five-four decision ${ }^{28}$ handed down at the end of the $1978 \mathrm{Term}$, attempted to delineate more precisely both the nature and significance of neutral principles as well as the limits of authorized judicial review of church-property disputes. Jones $v$. Wolf represents an express endorsement of the neutralprinciples method of adjudicating such disputes. At the same time, however, the opinion of the Court indicates that the doctrine of judicial deference to a hierarchical organization's internal authority remains a constitutionally acceptable, alternative mode of decision. By approving these seemingly contradictory approaches, Jones $v$. Wolf appears to leave state courts free either to treat hierarchical churches as any other voluntary association or to accord them preferential treatment by deferring to the resolution reached by the chosen body of the hierarchy.

In view of the efforts exerted by both the majority and the dissent to define the principles governing prior opinions, Jones $v$. Wolf is bound to become the focus of much future debate. Its appearance thus makes it appropriate to review once again the doctrinal development of the law in prior Supreme Court decisions. An examination of prior opinions-distinguishing the particular contexts and considerations involved in those decisions-may provide some understanding of the inherent tension in the body of law pertaining to church-property disputes.

This apparent tension has recently been explained as a manifestation of the "irreconcilable conflict" between religious community, which is furthered by judicial nonintervention in church disputes, and religious autonomy, which may be compromised if

25 See note 115 infra.

26 See note 116 infra.

27443 U.S. 595 (1979).

$28 \mathrm{Mr}$. Justice Blackmun delivered the opinion of the Court in which Justices Brennan, Marshall, Rehnquist, and Stevens joined. Mr. Justice Powell wrote the dissent joined by Chief Justice Burger and Justices Stewart and White. 
such nonintervention subjects dissident church groups to "unbounded domination by oppressive religious authorities." 29 It has also been observed that the difficulties in resolving church quarrels stem from the more fundamental problem of reconciling the parallel protections of the free exercise and nonestablishment provisions of the first amendment. This is said to be so because "each party to an intrachurch dispute can lay claim to the protections offered by one of the religious clauses." 30

This Article suggests, to the contrary, that at least in the area of church disputes over property, the two religion clauses each work to the same end. Relying on the conception that "the religion clauses were not separate mandates but a single one and that the underlying proposition was assurance of equality of treatment," 3I it proposes that "neutral principles of law" constitute not merely a permissible but the constitutionally required mode for resolving church-property disputes. Although based on a belief that religious liberty will be furthered by a separation of church and state, judicial deference to a hierarchical church's internal authority, when premised upon the assumption that members of a competing group voluntarily have submitted their property to the control of that authority, places the imprimatur of secular authority behind a particular form of religious organization-thereby implicating the establishment clause. At the same time, it also interferes with the freedom of individuals and groups to associate on their own terms for religious purposes.

\section{Foundations of the Deference Doctrine}

\section{A. Watson v. Jones: Churches as Voluntary Associations}

The seminal Supreme Court decision concerning judicial review of disputes over church property is Watson $v$. Jones, ${ }^{32}$ decided in 1871. Watson dealt with a struggle between two rival factions of the Walnut Street Presbyterian Church of Louisville, Kentucky, for control of the church premises. Organized about 1842 under the authority and as part of the Presbyterian Church of the United States, the Walnut Street Church in 1853 purchased a parcel of real estate in Louisville, the title to which was conveyed to the trustees of the local church. The deed to the property as well as the charter

29 L. TrRBE, supra note $9, \$ 14-12$, at 880 .

80 Wrs. Note, supra note 9 , at 925 .

81 Kurland, The Irrelevance of the Constitution: The Religion Clauses of the First Amendment and the Supreme Coust, 24 Vir.. L. Rev. 3, 24 (1978-79).

8280 U.S. (13 Wall.) 679 (1871). 
of the local church, however, "subjected both property and trustees alike to the operation [of the general church's] fundamental laws." 83 According to these laws, the General Assembly of the Presbyterian Church of the United States possessed "the power of deciding in all controversies respecting doctrine and discipline." 34

In 1865, the General Assembly adopted a resolution that required members of the congregation who adhered to the concept of the divine character of slavery to "repent and forsake these sins." 35 Contending that this resolution was contrary to a provision in the constitution of the Presbyterian Church, the minority faction of the local congregation seized control of the church property and severed its affiliation with the Presbyterian Church. The General Assembly responded by excluding the pro-slavery minority from any affiliation with the general church and by declaring the antislavery faction to be the true and lawful Walnut Street Church. ${ }^{36}$

After unsuccessful litigation in the state courts, ${ }^{37}$ representatives of the antislavery, majority faction instituted a diversity suit in federal court. ${ }^{38}$ The circuit court sustained the majority's claim for injunctive relief, which assured its control of the property, and the minority faction appealed to the Supreme Court. There, the dissidents, maintaining that the local church property was held for the use of the local church congregation subject to an implied trust in favor of the doctrine to which the property was devoted, urged the Court to invoke the "implied trust" and "departure:

33 Id. 683. The trustees were to be selected by the members of the congregation. Id.

\$4 Id. 682.

35 As a result of the dispute over slavery, the Presbytery of Louisville, possessing immediate jurisdiction over the Walnut Street Church, adopted " $A$ Declaration and Testimony against the erroneous and heretical doctrines and practices which have obtained and been propagated in the Presbyterian Church of the United States during the last five years" in which it condemned "the usurpation of authority" by the General Assembly. Id. 691 (emphasis in original).

In the main, religious schisms in the United States have been occasioned by economic and political differences, rather than by theological or ecclesiastical disagreements. The issue of slavery was particularly divisive of religious associations. W. Sperrx, supta note 5, at 77; W. SpErRY, Religion and OUR Divmed Denominations (1945).

3680 U.S. ( $13 \mathrm{Wall}$ ) ) at 692.

37 Watson v. Avery, $65 \mathrm{Ky}$. (2 Bush) 332 (1867). The Kentucky court held that a General Assembly decision was ultra vires under the church constitution, and ruled in favor of the pro-slavery minority.

88 The suit was brought by three petitioners who lived across the state line in Indiana. 80 U.S. (13 Wall.) at 694. The Court denied that the Kentucky court's judgments were res judicata because the state court was concerned merely with the legitimacy of the defendants election as elders. Id. 715-17. 
from-doctrine" standard. ${ }^{39}$ On this theory, control over property contributed to a church is based on adherence to the fundamental tenets in effect at the time the contribution was made. The antislavery position taken by the general Presbyterian Church, the minority faction claimed, constituted a departure from traditional doctrine in contravention of the avowed purposes of the alleged trust. The majority faction thus was said to have forfeited its control over the property when it followed the general church and repudiated the original, pro-slavery doctrine. As the local faction adhering to and maintaining the original church tenets, the minority maintained that it was entitled to control the property.

Mr. Justice Miller, writing for the Court, refused either to imply a trust in favor of the adherents to original church doctrine or to apply the departure-from-doctrine standard advocated by them. Inasmuch as the approach espoused by the dissidents would require civil courts to resolve ecclesiastical questions concerning "the true standard of faith in the church organization, and which of the contending positions before the court holds to this standard," ${ }^{40} \mathrm{Mr}$. Justice Miller found it incompatible with "the full and free right to entertain any religious belief" ${ }^{41}$ enjoyed in this country. Instead, he professed to promote the freedom of all religious groups by treating them equally with other voluntary associations. "Religious organizations," he declared, "come before us in the same attitude as other voluntary associations . . . and their rights of property, or of contract, are equally under the protection of the law, and the actions of their members subject to its restraints." 42

The underlying rationale for the Court's opinion thus was contractual.43 Individuals or groups may affiliate themselves for

30 The "implied trust" and "departure-from-doctrine" standard is of English origin and apparently was first articulated by Lord Eldon in Craigdallie v. Aikman, 3 Eng. Rep. 601, 606 (H.L. 1813). Lord Eldon ruled in favor of a minority religious body's withdrawal from the established Church of Scotland because the latter had deviated from the doctrine set forth by the founders of the church. For discussions of the English origins of the implied trust and departure-fromdoctrine standard, see Kauper, supra note 9, at 349-56; HARv. Note, supra note 1 , at $1145-49$.

4080 U.S. ( 13 Wall.) at 727. The Court also rejected the petitioners' contion that the church property in dispute was in fact devoted to the support of a specific body and doctrine. It maintained instead that this property was "acquired ... for the general use of a religious congregation" connected with a general church organization "by religious views and ecclesiastical government." Id. 726.

41 Id. 728.

42 Id. 714.

43 See generally Wis. Note, supra note 9 , at 909-13. 
religious purposes with any other individuals or groups they choose-apparently, on any terms-without interference from the courts. When an individual or group enters into a legitimate agreement, however, the courts will not justify failure to perform as agreed on grounds of religious freedom. Consistent with this approach, the Court enunciated the general principle that in disputes over property acquired for the use of a religious congregation, the group "ascertained to be that congregation, or its regular and legitimate successor, . . . is entitled to the use of the property." 44

Application of the contractual approach was intended to vary with the nature of the property conflict. In particular, Mr. Justice Miller distinguished three categories of disputes. The first involves property subject to an express trust dedicating the property to the support of a specific doctrine. ${ }^{45}$ The second concerns disputes involving what he termed "strictly independent" congregations.48 The third category encompasses disputes in hierarchical churches which arise "where the religious congregation ... holding the property is but a subordinate member of some general church organization in which there are superior ecclesiastical tribunals with a general and ultimate power of control more or less complete, in some supreme judicatory over the whole membership of that general organization." 47

Only in the case of a strictly congregational or independent church would a property dispute be resolved according to "the ordinary principles which govern voluntary associations." 48 Absent

4480 U.S. (13 Wall.) at 726.

45 Id. 722. Property disputes in which there had been an express dedication for a particular purpose presented no problems of adjudication to the Watson Court. The rules of construction generally applicable to charitable trusts seemed "equally applicable to ecclesiastical matters." Id. 723; see also note 72 infra.

46 Id. 722.

47 Id. $722-23$ (emphasis added).

$48 \mathrm{Id}$. 725. Justice Miller's statement of the rule applicable to congregational churches is consistent with the neutral-principles approach set forth in this Article. Because it uses principles derived from the law governing voluntary associations, it treats religious groups in a manner equivalent to all other private organizations. It requires no inquiry into doctrine.

This approach had been used prior to Watson o. Jones for resolution of congregational disputes. The problems with this approach were, however, part of the reason for adherence to the implied-trust doctrine. The implied-trust doctrine was applied to prevent "manipulation by a shifting and impermanent temporal majority [which would] cause a deviation from established doctrine." Kauper, supra note $\theta$, at 355. Thus, invalidation of the implied-trust doctrine and its correlative departure-from-doctrine standard may have invited greater denominational instability among congregational churches. The effect of Watson on congregational churches is discussed at length in Casad, The Establishment Clause and the Ecumenical Movement, 62 Mrcr. L. REv. 419 (1964). 
any designated tribunal or officers instituted by the congregation for purposes of ecclesiastical government, the congregation's majority would control the right to use the property. In contrast, the Court's opinion did not require, indeed it prohibited, an examination into the form of government adopted by a local congregation upon association with a hierarchical church. Rather, civil courts were to ascertain the legitimate successor to church property in a hierarchical dispute by determining which group is so recognized by the highest church judicatory and by deferring to that finding. "All who unite themselves to such a body," wrote Mr. Justice Miller, "do so with an implied consent to this government, and are bound to submit to it." 40 Accordingly, "the rule of action which should govern the civil courts" was that "whenever the questions of discipline, or of faith, or ecclesiastical rule, custom, or law have been decided by the highest . . . church judicator[y] .... the legal tribunals must accept such decisions as final, and as binding on them." 50 Watson $v$. Jones thus rejected the impliedtrust theory which bound the general church to a particular doctrine and replaced it with an implied-consent theory which conjoined the local church to the general church in all matters.

Application of the approach set forth in Watson $v$. Jones for the resolution of church-property disputes posed few difficulties. ${ }^{51}$ Once civil courts found implied consent on the part of a local church to be bound to a general church organization, the crucial determination then became the characterization of the church polity as either congregational or hierarchical. When a church's organizational structure was ascertained to be hierarchical, the action or judgment of the highest church tribunal was conclusive on the civil court. ${ }^{62}$

\section{B. Qualifications to Deference Doctrine}

The deference doctrine enunciated in Watson $v$. Jones, if strictly applied in conjunction with the principle of implied consent, would allow a hierarchical church judicatory almost un-

4980 U.S. ( 13 Wall.) at 729.

50 Id. 727.

51 See generally Wis. Note, supra note 9 , at 910.

52 That Watson 0 . Jones resulted in this pattern in the state courts is ironic. As it was admitted in Watson that the local church had bound itself and its property to the general church's control, the principle of implied consent was unnecessary to the decision in that case. See note 33 supra \& accompanying text. 
limited authority over its associated churches. ${ }^{53}$ Subsequent decisions, reflecting this concern, defined certain limited exceptions to the Watson rule and imposed on church tribunals minimal fairness requirements.

Bouldin v. Alexander, ${ }^{54}$ decided one year after Watson, dealt with a property dispute between competing factions of a congregational church, both of which claimed to represent the church. In a unanimous decision, the Supreme Court endorsed judicial inquiry into the structure of a church's organization for the purpose of determining which of the two groups actually represented the ultimate authority within the church. Some years later in Brundage v. Deardorf, ${ }^{55}$ Judge (later Chief Justice) Taft refused to extend Watson's deference rule to similar actions taken by the judicatory of a hierarchical church that were perpetrated "in fraud of the rights of a minority seeking to maintain the integrity of the original compact" 56 under which the affiliation was established. Judge Taft conceded that under Watson civil courts generally may not interfere with the right of a church's governing body to construe the limitations of its own power, but instead must accept such determinations as conclusive. He insisted, however, that Watson did not apply to an "open, flagrant, avowed violation" 57 of the contract under which church property became vested in the hierarchical organization. "Certainly, the effect of Watson $v$. Jones," he wrote, "cannot be extended beyond the principle that a bona fide decision of the fundamental law of the church must be recognized as conclusive by civil courts." 58

In Gonzalez v. Roman Catholic Archbishop of Manila, ${ }^{59}$ the Supreme Court, in a dictum written by Mr. Justice Brandeis, not

53 Permitting civil-court inquiry into the construction and application of church law by authoritative church tribunals, stated Mr. Justice Miller, "would, in effect, transfer to the civil courts where property rights were concerned the decision of all ecclesiastical questions." 80 U.S. (13 Wall.) at 734. "It is of the essence of these religious unions, and of their right to establish tribunals for the decision of questions arising among themselves, that those decisions should be binding in all cases of ecclesiastical cognizance." Id. 729. Having agreed to abide by the determination of the hierarchical-church tribunal, neither party should have recourse to review of such decisions by a civil court.

5482 U.S. ( 15 Wall.) 131 (1872).

5555 F. 839 (N.D. Ohio 1893), reo'd, 92 F. 214 (6th Cir. 1899). The reversal by the circuit court was based on a different construction of the facts in the case.

58 Id. 847-48.

57 Id. 846.

58 Id. 847.

59280 U.S. 1 ( 1928 ). 
only endorsed Judge Taft's modification of Watson, but extended it to include actions of church tribunals that were either collusive or arbitrary. In the absence of fraud, collusion, or arbitrariness, however, civil courts must accept as conclusive church court determinations of ecclesiastical matters. ${ }^{60}$ These decisions, although qualifying Watson, steadfastly adhered to its contractual rationale. Thus, Mr. Justice Brandeis explicitly justified civil-court deference to decisions of proper church tribunals on the ground that the parties in interest had agreed to accept their determinations as conclusive, "by contract or otherwise." 61

\section{Constitutional Consideration of Church-Property DISPUTES}

\section{A. The Deference Doctrine}

After the first amendment was held applicable to the states, ${ }^{62}$ the deference rule delineated in Watson $v$. Jones, ${ }^{63}$ was transformed from a common-law precept to a constitutional principle. Kedroff v. Saint Nicholas Cathedral os was the first case that explicitly grounded the deference rule in the free exercise clause. At issue in Kedroff was the constitutionality of a New York statute that sought to transfer administrative control over the Russian Orthodox churches of New York from the central governing hierarchy of the Russian Orthodox Church in Moscow to the governing authorities of the Russian Orthodox Church in America. In the Court's view, resolution of the property question depended on which church organization had the power to appoint the prelate of the New York diocese. ${ }^{65}$ Invoking the Watson doctrine of deference to decisions of authoritative hierarchical-church tribunals, the Court determined that, because the central governing hierarchy had the right to appoint the Bishop of the Archdiocese of North America, New York's statute constituted an infringement of the general church's free-exercise right under the first amendment. "Freedom to select the clergy, where no improper methods of choice are proven," the Court concluded, "must now be said to have federal

60 Id. 16.

B1 Id.

62 See note 10 supra.

6380 U.S. (13 Wall.) 679 (1871).

64344 U.S. 94 (1952). For a critical analysis of Kedroff, see YaLE Note, supra note 1.

65 344 U.S. at 96-97. 
constitutional protection as part of the free exercise of religion against state interference." 86

The Supreme Court's decision in Kedroff thus reaffirmed the Watson deference rule and indeed accorded it constitutional status under the free exercise clause. Decisions of authoritative hierarchical-church tribunals concerning ecclesiastical matters, when exercised pursuant to the consent of member churches, must be accepted as conclusive by civil courts unless fraudulent, collusive, or arbitrary. The Court did not explicitly address, however, the propriety of Watson's dictum that local churches, by affiliating themselves with a hierarchical church, may be held to have voluntarily submitted themselves to the ecclesiastical authority of the general church with respect to all matters. ${ }^{67}$ To the contrary, the Court in Kedroff prefaced its discussion of Watson by pointing out that the earlier decision was based not merely upon the hierarchical nature of the organization in question, but also on the fact that the local church, its property, and its officers were subject to the control of the general church.

Similarly, the Court in Kedroff premised its decision on the finding that the Russian Orthodox Church held administrative control over the North American diocese, including the power to appoint all clergy. ${ }^{68}$ This suggests that the Kedroff Court's elevation of the deference doctrine to constitutional status was not meant to extend similar status to Watson's implied-consent dictum. Such a conclusion is buttressed by a footnote in which the Court stated that the principle of judicial "nonreviewability" is justifiable only "when [it is] within the 'express or implied stipulations' of the agreement of membership." 69

66 Id. 116. Kedroffs holding invalidating this legislative action was extended to judicial action in Kreshik v. Saint Nicholas Cathedral, 363 U.S. 190 (1960). In Kreshik the Court reversed a New York state court judgment that transferred control of Saint Nicholas Cathedral from the central governing authority of the Russian Orthodox Church to the Russian Church of America. See also Presbyterian Church v. Mary Elizabeth Blue Hull Memorial Presbyterian Church, 393 U.S. 440, 448-49 (1969).

67 The Court expressly noted: "The opinion of this Court [in Watson] assumed without question that the Louisville church, its property and its officers were originally and up to the beginning of the disagreements subjected to the operation of the laws of the General Assembly of the Presbyterian Church." 344 U.S. at 111.

68 Id. 105-06.

69 Id. 115 n.20 (quoting Watson v. Jones, 80 U.S. ( 13 Wall.) at 733). Mr. Justice Reed recognized the "vivid and strong criticism" of Watson's statement that civil courts may not examine a church-court conclusion as to "a subject-matter of dispute, strictly and purely ecclesiastical in its character." II. See C. ZoLrimaN, Anderican Churce Law 291 (1933). 
B. Unconstitutional Judicial Inquiry: The Implied Trust and Departure-from-Doctrine Standard

Despite the express disapproval in Watson $v$. Jones of an implied-trust theory based on adherence to church doctrine, many state courts continued to apply variations of that rule as a matter of state common law.70 In Presbyterian Church v. Mary Elizabeth Blue Hull Memorial Presbyterian Church, ${ }^{71}$ the Supreme Court finally gave definitive consideration to the constitutional validity of the implied-trust theory and its correlative departure-from-doctrine standard. Presbyterian Church presented a hierarchicalchurch dispute between a general church and two of its local member churches over the right to use and control the local churches' property. The controversy began when the local churches claimed that the general church had violated the organization's constitution and had departed from accepted doctrine and practice. At the time, Georgia law implied a trust of local church property for the benefit of the general church on the condition that the general church adhere to doctrinal tenets existing at the time of affiliation of the local churches. On the basis of a jury finding that the general church had substantially abandoned its original doctrines, the Georgia Supreme Court upheld the right of the local congregations to withdraw from general-church organization and to retain control of their property.

The Supreme Court, holding that such civil-court inquiry into church doctrine violated the first amendment, reversed the state court. Because questions of doctrine and practice are matters of purely ecclesiastical concern, the Court reasoned, civil-court inquiry into such questions under the departure-from-doctrine standard is constitutionally impermissible. The Court concluded that "the departure-from-doctrine element of Georgia's implied trust theory can play no role in any future judicial proceedings. The departure-from-doctrine approach is not susceptible of the marginal judicial involvement contemplated in Gonzalez [v. Roman Catholic Archbishop of Manila].” 72

70 See generally Casad, Church Property Litigation: A Comment on the Hull Church Case, 39 Geo. Wase. L. Rev. 44, 56 (1970).

71393 U.S. 440 (1969).

72 Id. 450 (emphasis in original). In a footnote to this statement the Court expressly left open the question of "the precise limits of review for 'fraud, collusion, or arbitrariness' within the meaning of Gonzalez." Id. 450 n.7. See notes 59-61 supra \& accompanying text.

In a concurring opinion, Mr. Justice Harlan stated that he did not "read the Court's opinion to go further to hold that the Fourteenth Amendment forbids civilian courts from enforcing a deed or will which expressly and clearly lays down 
Apart from invalidating the departure-from-doctrine approach, the Court in Presbyterian Church was content to remand the case to the state court with a general admonition that church-property conflicts be decided "without resolving underlying controversies over religious doctrine." 73 Despite its apparent endorsement of the Watson deference doctrine, however, the Supreme Court did not recommend to the state court that it yield to the determination of the pertinent governing church body. Instead, the Court emphasized that, although the first amendment "severely circumscribes" the nature of permissible judicial intervention in disputes over church property, "not every civil court decision as to property claimed by a religious organization jeopardizes values protected by the first amendment." 74 In particular, the Court instructed that "neutral principles of law, developed for use in all property disputes" 75 can be applied by civil courts to adjudicate these controversies. The Court then assigned to both the states and the churches themselves the responsibility for ordering the use and control of church property in ways that would obviate the need for civil-court inquiry into ecclesiastical questions. ${ }^{76}$

\section{Neutral Principles Applied: Sharpsburg}

The Court's opinion in Presbyterian Church offered no guidance regarding the determination or application of neutral principles and failed to explain the correlation, if any, between the neutral-principles approach and the deference rule of Watson $v$. Jones. To some observers, the Court's endorsement of neutralprinciples excluded Watson's doctrine of judicial deference to church authority "as a rule not 'developed for use in all property disputes." "77 Others viewed the language of the Court's opinion,

conditions limiting a religious organization's use of the property which is granted." 393 U.S. at 452 (Harlan, J., concurring).

73 Id. 449.

$74 \mathrm{Id}$.

$75 \mathrm{Id}$.

${ }^{76}$ Id. On remand, the Georgia Supreme Court reasoned that because Georgia chose to adopt the implied-trust theory with the departure-from-doctrine element as a condition, "it would not have adopted the theory without" the departurefrom-doctrine element. Presbyterian Church v. Eastern Heights Presbyterian Church, 225 Ga. 259, 260, 167 S.E.2d 658, 659 (1969), cert. denied, 396 U.S. 1041 (1970).

Finding no other basis for a trust of the local church property for the general church in either the language of the deeds or in the constitution of the general church, the court rendered judgment in favor of the respective local churches.

77 See, e.g., The Supreme Court, 1968 Term, 83 Harv. L. Rev. 7, 129 (1969) (quoting in part Presbyterian Church o. Mary Elizabeth Blue Hull Memorial Presbyterian Church, 393 U.S. at 449). 
if not its substance, as indicating that churches would in the future be treated "like any other voluntary association." 78

Maryland and Virginia Eldership v. Church of God at Sharpsburg, Inc., ${ }^{78}$ decided the following term, provided the Supreme Court with an occasion to recognize and approve an appropriate application of "neutral principles of law" to a church-property dispute. In Sharpsburg, majorities in two individual congregations of the Church of God separately purported to withdraw themselves and their property from association with the Maryland and Virginia Eldership of the Church. Refusing to recognize the withdrawal, the eldership issued a judgment which declared that the local minorities in each church group constituted the "true congregation" and therefore retained all property rights in the local churches. ${ }^{80}$ The eldership subsequently brought suit against the secessionist congregations, seeking to prevent their withdrawals and asking that the minority factions be adjudged the rightful owners of the local church property. Sharpsburg was pending before the Supreme Court when the opinion in Presbyterian Church was announced, and accordingly was remanded for further consideration in light of that ruling. On remand, the Maryland Court of Appeals reviewed its previous decision and concluded that it had anticipated Presbyterian Church and properly applied the neutral-principles approach subsequently invoked in that decision.

While noting the importance of the question of church polity in considering church-property disputes, the Maryland court had pointed out in its initial opinion that "merely because a denomination has some of the characteristics of one type of polity, some of the characteristics of other polities are not excluded." 81 Although the court recognized several methods by which general churches may secure control over the property of associated local churches, ${ }^{82}$

78 See e.g., Kauper, supra note 9, at 375 (footnote omitted).

79249 Md. 650, 241 A.2d 691 (1968), vacated and remanded, 393 U.S. 528, reaffd, 254 Md. 162, 254 A.2d 162 (1969), appeal dismissed, 396 U.S. 367 (1970).

80 As the Maryland court noted, the judgment of the General Eldership declared "that all persons who voted to withdraw from the Md. \& Va. Eldership have: : . abandoned and forfeited all rights, privileges, properties and offices in the local church and in the Churches of God. . . . In each local church the members who continue to adhere and submit to the doctrines and the policy of the denomination constitute the true congregation." $249 \mathrm{Md}$. at $655,241 \mathrm{~A} .2 \mathrm{~d}$ at 694 .

81249 Md. at 664, 241 A.2d at 698-99.

82 The Court explicitly defined three methods by which a hierarchical denomination may maintain control of local church property: 
it insisted that the mere fact of some hierarchical connection with a general church does not preclude that local church from retaining its right as a congregation to use and control local church property. After examining the applicable state statutes governing the holding of church property, the terms of the instrument deeding the property to the local churches, and the pertinent provisions of the general-church constitution and the local-church charters, the Maryland court concluded that the majority factions, consistent with the first amendment, could withdraw from the general organization and retain control over the properties of the respective local churches. In its decision on remand, the court noted that the implied trust and departure-from-doctrine standard were never part of Maryland's law, and claimed that it therefore was "required by the existing Maryland law as well as by the command of Hull [Presbyterian Church] to decide the present case upon neutral principles of law." ${ }^{83}$ The court then exhaustively examined its earlier decision, and held that it was strictly in accord with the neutral-principles approach approved in Presbyterian Church. ${ }^{84}$

The Supreme Court, in a per curiam opinion, dismissed an appeal from the decision of the Maryland court for lack of a substantial federal question. ${ }^{85}$ Dismissal was warranted, the Court explained, because "the Maryland court's resolution of the dispute involved no inquiry into religious doctrine." 86

1. It may require reverter clauses in the deeds to the property of the local churches.

2. It may provide in its constitution or by some other authoritative source for the reverting of the local church property to the hierarchical body upon withdrawal by the local congregation with an implied consent by the local church to this provision.

3. It may obtain from the [State] General Assembly an act providing for such a result.

$249 \mathrm{Md}$. at $633,241 \mathrm{~A} .2 \mathrm{~d}$ at 699.

$83254 \mathrm{Md}$. at $166,254 \mathrm{~A} .2 \mathrm{~d}$ at 165.

84 The Maryland court noted that to prevent the local congregations from separating from the Eldership "would deny to the members of the local congregation their freedom of religion and would in effect put the judicial power of the State behind the enforcement of the doctrine and discipline of the EIdership thus, in effect, "establishing' the religion promulgated by the Eldership." $254 \mathrm{M}$. at 175,154 A.2d at 170 (emphasis in original).

85396 U.S. at 367 . The Supreme Court has held that a dismissal for lack of a federal question is a judgment on the merits of the case. Hicks v. Miranda, 422 U.S. 332,344 (1975).

88396 U.S. at 368 . In a concurring opinion, Mr. Justice Brennan restated the command expressed in Presbyterian Church, that civil courts must "decide church property disputes without resolving underlying controversies over religious doctrine." Id. (Brennan, J., concurring) (quoting Presbyterian Church v. Mary Elizabeth Blue Hull Memorial Presbyterian Church, 393 U.S. 440, 449 (1969)). Apparently trying to reconcile his twin endorsements in Presbyterian Church of 
D. Serbian Eastern Orthodox Diocese v. Milivojevich: The Demise of Neutral Principles?

The constitutional validity of the neutral-principles approach was soon rendered uncertain by the Supreme Court's pronouncement in Serbian Eastern Orthodox Diocese v. Milivojevich, ${ }^{87}$ which appeared to extend significantly the limits of the deference doctrine of Watson $v$. Jones, at the expense of the neutral-principles approach. ${ }^{88}$

At stake in Serbian was control of the property and assets of the Serbian Eastern Orthodox Diocese for the United States, a constituent part of the hierarchical Serbian Eastern Orthodox church, (the mother church) that was headquartered in Yugoslavia. In May 1963, the highest authority of the mother church, the Holy Assembly of Bishops, suspended Bishop Milivojevich and reorganized into three dioceses the American-Canadian Diocese that Milivojevich had headed. When Milivojevich refused to recognize either his suspension or the diocesan reorganization, he was defrocked by the Holy Assembly. Milivojevich responded by convening the American-Canadian Diocesan National Assembly, which attempted to circumvent the reorganization scheme by revising the constitution and by declaring itself autonomous. ${ }^{89}$ The Illinois Supreme Court, considering the validity of the reorganization, concluded that the defrockment had been arbitrary and therefore invalid, and that the mother church lacked the authority to reorganize the diocese. ${ }^{90}$ The United States Supreme Court reversed, and sharply criticized the rejection by the Illinois court of the decision

both the modified Watson deference rule and the neutral-principles approach, however, he also approved the converse proposition that states may alternatively "adopt any one of various approaches for settling church property disputes so long as it involves no consideration of doctrinal issues." Id. 368. Mr. Justice Brennan then suggested that both the modified Watson deference rule and a neutralprinciples approach were acceptable alternative methods of adjudication. Id. 368-70.

87426 U.S. 696 (1976).

88 McKeag, The Problem of Resolving Property Disputes in Hierarchical Churches, 48 PA. B.A.Q. 281 (1977); WIs. Note, supra note 9, at 920-26; Note, Serbian Eastern Orthodox Diocese v. Milivojevich, The Continuing Crusade for Separation of Church and State, 18 WM. \& MART L. REv. 665 (1977); 45 FORDHAM L. REv. 992 (1977).

89 Representatives of the Serbian Eastern Orthodox Church subsequently brought suit against Bishop Milivojevich and the Illinois corporation that held the church property, and requested the trial court to find that Milivojevich had been properly removed as bishop and that the diocesan reorganization ordered by the Holy Assembly was valid. Bishop Milivojevich counterclaimed, seeking a determination that his defrockment had been arbitrary and an injunction enjoining the plaintiffs from interfering with the assets of the religious corporations.

9060 III. 2 d 447, 328 N.E.2d 268 (1975). 
of the mother church's highest ecclesiastical tribunal.91 The Supreme Court instructed that:

where resolution of [church] disputes cannot be made without extensive inquiry by civil courts into religious law and polity, the First and Fourteenth Amendments mandate that civil courts shall not disturb the decisions of the highest ecclesiastical tribunal within a church of hierarchical polity, but must accept such decisions as binding on them, in their application to the religious issues of doctrine or polity before them. ${ }^{92}$

To many, this language introduced a "standard of strict nonintervention" into the area of hierarchical-church disputes. ${ }^{93}$ Commentators read the Court's decision as undercutting the contractual rationale of Watson $v$. Jones ${ }^{94}$ and as presaging the demise of the neutral-principles approach..$^{95}$ Close examination of the Court's opinion reveals, however, that the actual decision is much narrower than the passage quoted above implies. The Court's analysis actually affirms Watson's consensual basis and does not in any way threaten the vitality of neutral principles.

The Supreme Court concluded that the Illinois court had transgressed the boundary of permissible review on two counts. As both parties had agreed that the "sole power to appoint and remove Bishops of the Church reside[d] in its highest ranking organs," 86 the state court, in finding for Milivojevich, relied on the "arbitrariness" exception of Gonzalez v. Roman Catholic Archbishop of Manila. ${ }^{97}$ In so doing, it had engaged in an extensive interpretation

91 Serbian E. Orthodox Diocese v. Milivojevich, 426 U.S. 696, 708-25 (1976). 92 Id. 709.

93 See note 88 supra \& accompanying text.

94 "The effect of Milivojevich is to severely circumscribe court activity in intrachurch disputes and to render the theoretical basis of this area of law, formerly one of contract, uncertain." Wis. Note, supra note 9 , at 924 . "The decision thus undercuts the contractual rationale of Watson that provided the basis for the rule of deference to hierarchical tribunals." Id. 927.

95 [Serbian] would seem to signal the demise of the neutral principles of law approach in adjudicating disputes within hierarchical churches.

....

Thus a rule emerges as to hierarchical churches that is clear and definitive-the decision of a hierarchical church tribunal is final. Neutral principles of law may not be used in the future to review those decisions .....

45 Fordhax L. Rev. 992, 1000-01 (1977).

96 Serbian E. Orthodox Diocese v. Milivojevich, 426 U.S. at 715.

97280 U.S. 1 (1929). See notes 59-61 supra \& accompanying text. 
of church laws and procedures. The Supreme Court found constitutionally impermissible this interpretation of "quintessentially religious" controversies "under the guise of 'minimal' review under the umbrella of "arbitrariness." "98 Instead of simply rejecting this approach, however, the Court expressly abolished the arbitrariness exception. ${ }^{90}$

In addition, the Illinois court held the diocesan reorganization to be invalid on the ground that it "was "in clear and palpable excess of [the Holy Assembly's] jurisdiction.' "100 To reach this conclusion, the court undertook an examination of the constitutions of both the mother church and of the American diocese. It characterized its interpretation of the scope of the mother church's jurisdiction as an application of "neutral principles," which would not "entangle this court in the determination of theological or doctrinal matters." 101 The Supreme Court also rejected this approach. Noting that the American-Canadian Diocese in fact had subordinated itself to the mother church in matters administrative as well as ecclesiastical, ${ }^{102}$ it held that the ruling of the Illinois court abridged the first amendment. The state court had "substituted its interpretation of the Diocesan or Mother church constitution for that of the highest ecclesiastical tribunals in which church law vests authority to make that interpretation." 103

Thus, Serbian actually reaffirmed the consensual rationale of Watson $v$. Jones and, by implication, elevated it to constitutional status. ${ }^{104}$ If the parties to an intrachurch dispute have agreed to be bound by an ecclesiastical tribunal's decision in particular cases, a civil court may not determine whether that tribunal has adhered

38426 U.S. at 720 .

99 [W] hether or not there is room for "marginal civil court review" under the narrow rubrics of "fraud" or "collusion" when church tribunals act in bad faith for secular purposes, no "arbitrariness" exception-in the sense of an inquiry whether the decisions of the highest ecclesiastical tribunal of a hierarchical church complied with the church laws and regulations-is consistent with the constitutional mandate that civil courts are bound to accept the decisions of the highest judicatories of a religious organization of hierarchical polity on matters of discipline, faith, internal organization, or ecclesiastical rule, custom, or law.

Id. 713 (footnote omitted).

100 Serbian E. Orthodox Diocese v. Milivojevich, 60 Ill. 2 d at 507, 328 N.E.2d at 507, 328 N.E.2d at 284 (quoting Schweiker v. Husser, I46 Ml. 399, 425, 34 N.E. 1022,1030 (1893)).

10160 Ill. 2 d at 505, 328 N.E.2d at 282. See Serbian E. Orthodox Diocese v. Milivojevich, 426 U.S. at 721 .

102426 U.S. at 722 .

103 Id. 721.

104 Id. 713-14. 
to its own decisionmaking rules. Although Mr. Justice Rehnquist, joined in dissent by Mr. Justice Stevens, disputed the majority's conclusion that the American-Canadian Diocese and Bishop Milivojevich had agreed to abide by the mother church's decisions in matters at issue, he too accepted the "general principle that persons who have contractually bound themselves to adhere to the decisions of the ruling hierarchy in a private association may not obtain relief from those decisions in a civil court." 105

The criticism that Serbian, "[b]y countenancing violations of internal church law . . . thus disposes of the contractual theory of membership in hierarchical religious associations," 108 therefore appears to be unfounded. The Serbian Court did not hold that church laws embodying the terms of the contract "may not be examined"; ${ }^{107}$ rather, it determined upon examination that those laws manifested a voluntary agreement between the parties to abide by the decisions of the Holy Assembly. Indeed, it was the Court's strict enforcement of this agreement that led it to reject the inference drawn in Brundage v. Deardorf ${ }^{108}$ and Gonzalez $v$. Roman Catholic Archbishop of Manila, ${ }^{109}$ that consent to be governed does not extend to actions by church tribunals in disregard of the accepted laws of the church. In the face of such a compact, civil courts may intervene to preserve the autonomy of a local church, aggrieved by decisions of a hierarchical tribunal by which it has agreed to be bound, only if the tribunal has acted fraudulently or collusively. ${ }^{110}$

\section{Jones $v$. Wolf: Neutral Principles Reconsidered}

The combined effects of Presbyterian Church, ${ }^{111}$ Sharpsburg, ${ }^{112}$ and Serbian ${ }^{113}$ not only confused commentators, ${ }^{114}$ but also contributed to a series of conflicting decisions in state and lower federal courts. The resulting uncertitude was attributable, in the main, to

105 Id. 732 (Rehnquist, J., dissenting).

106 Wrs. Note, supra note 9 , at 922 .

$107 \mathrm{Id}$.

10855 F. 839 (N.D. Ohio 1893), rev'd, 92 F. 214 (6th Cir. 1899). See notes 55-58 supra \& accompanying text.

109280 U.S. I (1929). See notes 59-61 supra \& accompanying text.

110426 U.S. at 713.

111 Presbyterian Church v. Mary Elizabeth Blue Hull Memorial Presbyterian Church, 393 U.S. 440 (1969).

112 Maryland \& Va. Eldership v. Church of God at Sharpsburg, Inc., 396 U.S. 367 (1970).

113 Serbian E. Orthodox Diocese v. Milivojevich, 426 U.S. 696 (1976).

114 See note 88 supra. 
judicial divergence, following Serbian, regarding the validity of applying neutral principles in the face of a determination by a hierarchical-church tribunal on the issue in dispute. Some courts read Serbian as adopting a constitutional rule of compulsory deference in all cases to such determinations. ${ }^{118}$ Other courts rejected this approach in favor of a more narrow construction, one mandating deference to hierarchical bodies only when the dispute was not susceptible to resolution under a neutral-principles approach. ${ }^{116}$ To a significant extent, this divergence reflected uncertainty regarding the appropriate limits of judicial inquiry into the nature of religious associations. Apparently recognizing the need for a more definitive statement, the Supreme Court took the occasion in Jones $v$. Wolf ${ }^{117}$ to elaborate on the nature and significance of "neutral principles of law." Unfortunately, the Court's opinion appears to raise as many questions as it answers concerning the limits of authorized judicial review in church-property disputes.

\section{A. The Early History of the Case}

Jones $v$. Wolf arose out of a conflict between the Vineville Presbyterian Church of Macon, Georgia (VPC) and the Presbyterian Church in the United States (PCUS), one of several large Presbyterian denominations in this country. ${ }^{118}$ Unable to resolve their doctrinal differences, the congregation of VPC adopted, by a vote of 165 to 94 , a resolution which purported to separate the church and its property from continued affiliation with PCUS. The majority faction of the congregation immediately notified the AugustaMacon Presbytery of PCUS of this action, and subsequently joined with another Presbyterian denomination that was unaffiliated with PCUS. Following adoption of the resolution, the majority faction retained possession and control of VPC's property and assets. The

115 See, e.g., First Presbyterian Church v. United Presbyterian Church, 430 F. Supp. 450 (N.D.N.Y. 1977) (civil courts must defer to hierarchical-church decisions); Presbytery of the Covenant v. First Presbyterian Church, 552 S.W.2d 865 (Tex. Civ. App. 1977) (same).

116 See, e.g., Kelley v. Riverside Blvd. Independent Church of God, 44 III. App. 3d 673, 358 N.E.2d 696 (1976) (first amendment does not require deference to church-court decisions); Board of Church Extension v. Eads, 230 S.E.2d 911, 919 n.6 (W. Va. 1976) (deference to hierarchical-church-court decision required only when "a case is not susceptible to the application of completely neutral principles of law").

117443 U.S. 595 (1979).

118 Jones v. Wolf, No. 45787 D-2 (Bibb Super. Ct., filed Sept. 30, 1977). The parties entered into a written stipulation of facts, which was incorporated into the court's order and adopted in full as the court's findings of fact. Id. 
minority group ceased to participate in the affairs of VPC, and was refused the privilege of using VPC premises as an adjunct of PCUS.

Although the separation resolution was adopted, in conformity with PCUS's Book of Church Order, by a majority vote of the congregation, ${ }^{119}$ PCUS responded by appointing an administrative commission which issued an ex parte "ruling, order and judgment" that declared the minority faction the true congregation of VPC and withdrew from the majority faction all authority derived from PCUS. ${ }^{120}$ The commission's order purported further to retract all of the majority faction's ecclesiastical privileges and rights to VPC property.

Shortly thereafter, members of the minority faction brought an equitable action in the Georgia state court for a declaratory adjudication of their rights to exclusive use of VPC premises and for a permanent injunction preventing the majority group from continuing to use the property in any manner other than as a unit of PCUS. The petition asserted that the minority group was the true congregation as decreed by the PGUS commission and that the majority was "acting unlawfully in continuing to maintain possession and control of the church property to the exclusion" of the minority. ${ }^{121}$ The majority responded that it "had a right to withdraw from PCUS upon appropriate resolution of the congregation; that the PCUS commission had no authority over VPC property nor authority to name any of the petitioners as trustees of VPC," and that the majority held lawful possession and control of VPG premises. ${ }^{122}$

To the Georgia courts, Jones $v$. Wolf presented a typical church-property dispute between a local church, represented by the majority of its congregation, and a hierarchical religious society with which the local church was previously associated, represented by a minority faction of that local congregation. The trial court found that, at the time the separation resolution was adopted, the classes represented by the respective litigants together

119 Brief for Respondent at 4, Jones v. Wolf, 443 U.S. 595 (1979). "The PCUS Book of Church Order, 14th Printing (1972), was in effect at the time this controversy arose. Section 5-6 of the Book of Church Order provide[d] for the adoption of resolutions at congregational meetings by a majority vote." Id. 4 n.4. At that time, however, "the Book of Church Order contained no prohibition against the withdrawal of a congregation without the approval of PCUS, although such a provision was [subsequently] added, to the fifteenth printing at section 4-2." Id. 4 n.5.

$120 I d .4$.

121 Id. 5.

122 Id. 5-6 (footnote omitted). 
constituted the congregation of VPG, which in turn was a memberunit of the Augusta-Macon Presbytery of PCUS. Accordingly, the court described the legal issue presented as "the right to control church properties as between the central church organization (or a faction claiming under it) and the local church congregation when the latter becomes dissatisfied with the affiliation and seeks for whatever reason to withdraw." 123

Initially, the trial court recognized the constitutional requirement, enunciated in Presbyterian Church ${ }^{124}$ and reaffirmed in Serbian, ${ }^{125}$ that civil courts decide church-property disputes without resolving underlying controversies over religious doctrine. In professed compliance with this mandate, the court proceeded to adjudicate the dispute by employing the neutral-principles approach approved by the Supreme Court in Sharpsburg ${ }^{126}$ and subsequently adopted by the Georgia Supreme Court in Presbyterian Church $v$. Eastern Heights Presbyterian Church ${ }^{127}$ and Carnes v. Smith. ${ }^{128}$ These cases sanctioned civil-court examination of property deeds, state statutes regarding religious corporations, church corporate charters, and provisions in church constitutions-provided that such examination did not intrude into doctrinal matters. Applying these rules to the controversy at hand, the trial court found nothing in the pertinent documents to indicate any express or implied trust of VPC property in favor of any group other than VPC's local congregation. ${ }^{120}$ The court concluded as a matter of law that VPC was properly represented by the majority faction of the local church. In so doing, it expressly denied that PGUS possessed the authority to declare the minority group the true congregation, "for the purpose of creating a trust relationship with respect to the church property of VPC when none previously existed, expressly or by implication." 130

123 No. 45787 D-2 (Bibb Super. Ct., flled Sept. 30, 1977).

124 See notes 71-76 supra \& accompanying text.

125 See notes 87-110 supra \& accompanying text.

126 See notes 79-86 supra \& accompanying text.

127225 Ga. 259, 167 S.E.2d 658 (1969), cert. denied, 396 U.S. 1041 (1970).

128236 Ga. 30, 222 S.E.2d 322, cert. denied, 429 U.S. 868 (1976). Carnes involved a property dispute between the United Methodist Church and a local congregation that had withdrawn from that organization. The local congregation refused to allow the use of its property as part of the general United Methodist Church. The Georgia Supreme Court, applying "neutral principles," determined that the parties had contemplated that the local church would hold the church property in favor of the United Methodist Church, and accordingly affirmed the grant of an injunction awarding control of the property to that body. See Jones v. Wolf, 443 U.S. at 600-01.

129 No. 45787 D-2 (Bibb Super. Ct., filed Sept. 30, 1977).

$130 \mathrm{Id}$. 
On appeal, the minority faction again argued that it was entitled to the property because it had remained loyal to PGUS. The Georgia Supreme Court rejected this contention and affirmed the judgment of the trial court on the ground that "more than a mere connectional relationship between the local and general churches must exist to give rise to property rights in the general church." 131 Representatives of the minority faction thereafter petitioned the Supreme Court for a writ of certiorari. Pointing to the conflict and confusion among the states concerning the application of the first amendment principles enunciated in Presbyterian Church and Serbian, the petitioners urged the Court to provide a more definitive statement of the constitutional rules in this area. ${ }^{132}$

\section{B. The Supreme Court's Opinion}

\section{Endorsement of Neutral Principles}

The "question for decision" posed in Jones $v$. Wolf was defined by the Supreme Court as "whether civil courts, consistent with the First and Fourteenth Amendments to the Constitution, may resolve [a church-property] dispute on the basis of 'neutral principles of law, or whether they must defer to the resolution of an authoritative tribunal of the hierarchical church." ${ }^{133}$ Mr. Justice Blackmun, writing for the Court, prefaced his opinion by indicating the fundamental constitutional limitation that circumscribes the role civil courts may play in this area. "Most importantly," he declared, "the First Amendment prohibits civil courts from resolving church property disputes on the basis of religious doctrines and practice." ${ }^{134}$ As a "corollary to this commandment," ${ }^{135} \mathrm{Mr}$. Justice Blackmun asserted that, in regard to such religious matters, civil courts are constitutionally required to defer to the resolution reached within the religious association. Subject to these constraints, however, states are free to "adopt any one of various approaches for settling church property disputes so long as it involves no consideration of doctrinal matters, whether the ritual

131 Jones v. Wolf, 241 Ga. 208, 243 S.E.2d 860, 863 (1978), vacated, 443 U.S. 595 (1979).

132 Petition for a Writ of Certiorari at 6-18, Jones v. Wolf, 443 U.S. 595 (1979). The Supreme Court granted the writ of certiorari on October 10, 1978. 439 U.S. 891 (1978). In a decision on July 2, 1979, it vacated the judgment of the Supreme Court of Georgia and remanded the case for further proceedings consistent with its opinion. 443 U.S. 595 (1979).

133443 U.S. at 597.

134 Id. 602.

135 Id. 
and liturgy of worship or the tenets of faith." 136 Finding neutral principles, "[a]t least in general outline," 137 consistent with these constitutional limitations, the Court accordingly held that states are "constitutionally entitled to adopt neutral principles of law as a means of adjudicating a church property dispute." 138 Before considering whether the Georgia court properly applied such principles to the facts of the case, however, the Court, in an enthusiastic endorsement of that approach, elaborated for the first time upon the propriety of its general application.

At least as approved in Sharpsburg, the neutral-principles analysis involved a judicial examination of numerous sourcesincluding property deeds, relevant state statutes, and pertinent provisions in church documents-to determine the body in which the competing religious groups themselves originally intended to place ultimate authority over church property. Although this inquiry entailed a review of certain church documents, it was explicitly designed to avoid drawing civil courts into religious controversies. Rather, courts were to ascertain and effectuate the private arrangements of affiliated churches, as evinced by the terms of their association.

The endorsement in Jones $v$. Wolf of the neutral-principles method for settling church-property disputes reflects the Court's continued adherence to this contractual rationale. Indeed, the "peculiar genius" of this analysis, in the Court's view, consists essentially in its "flexibility in ordering private rights and obligations to reflect the intentions of the parties." 139 Because neutral principles do not purport to do anything other than resolve churchproperty disputes in accordance with the express or implicit desires of the litigants, "all forms of church organization and polity" 140 can be accommodated by this approach. Significantly, the four dissenting Justices also appeared to have accepted this same underlying rationale. While vigorously contesting both the Court's construction of neutral principles and the application of those principles to this particular case, the dissent maintained nevertheless that "[t]he proper rule of decision requires a court to give effect in all

136 Id. (quoting Maryland \& Va. Eldership v. Church of God at Sharpsburg, Inc., 396 U.S. 367, 368 (1970) (Brennan, J., concurring) (emphasis in original)).

$137 \mathrm{Id}$.

138 Id. 604.

130 Id. 603.

$140 \mathrm{Id}$. 
cases to the decisions of the church government agreed upon by the members before the dispute arose." 141

In certain respects, however, the Court's exposition of "neutral principles of law" seems to vary significantly, at least in emphasis, from prior statements of the doctrine. To begin with, the Court in Jones $v$. Wolf defined the appropriate objective of judicial inquiry into church documents and other relevant sources far more precisely than did earlier opinions. Under the Court's interpretation, civil courts adopting the neutral-principles approach must examine relevant evidentiary sources for the select purpose of determining "whether there [is] any basis for a trust [of local church property] in favor of the general church." ${ }^{142}$ The Court contrasted this limited inquiry with the dissent's broad contention that a civil court should examine relevant sources to ascertain the body in which competing church groups had placed ultimate authority over the church property. ${ }^{143}$ While the Court recognized that this task, in many cases, would not prove to be difficult, it nevertheless insisted that, in others, "the locus of control would be ambiguous," and that in such cases the dissent's approach "would appear to require 'a searching and therefore impermissible inquiry into church polity." " 144

Ostensibly, the explanation for the Court's more restrictive formulation of neutral principles is to be found in its professed desire to isolate decisions regarding church property from other determinations involving matters at the core of ecclesiastical concern. As viewed by the Court, the main attraction of neutral-principles analysis resides in its promise to free civil courts from entanglement in matters of religious doctrine, practice, and internal administration. Consistent with the admonition in Serbian that "a civil court must accept the ecclesiastical decisions of church tribunals as it finds them," ${ }^{145} \mathrm{Mr}$. Justice Blackmun's construction represented an attempt to remove from civil adjudication all "quintessentially religious" 146 questions. To this end, he instructed civil courts undertaking an examination of church documents to "take special care to scrutinize the document[s] in purely secular terms, and not to rely on religious precepts in determining whether

141 Id. 614 (Powell, J., dissenting).

$142 \mathrm{Id} .600$.

143 Id. 604-05.

144 Id. (quoting Serbian E. Orthodox Diocese v. Milivojevich, 426 U.S. 696, 723 (1976)).

145 Serbian, 426 U.S. at 713.

146 Id. 720 . 
the document[s] indicate $[$ that the parties have intended to create a trust." 147 Courts adopting this method for resolving churchproperty disputes must examine the parties' outward expressions of intent to determine whether they meant to place the right to control the property in someone other than the formal titleholder. The judicial inquiry must eschew reliance on religious precepts, however, and instead base its analysis solely "on objective, wellestablished concepts of trust and property law familiar to lawyers and judges." 148

2. The Decision to Remand: The Problem of Characterizing the Dispute

In view of its strong endorsement of the neutral-principles approach, the Supreme Court's actual disposition in Jones $v$. Wolf was somewhat surprising, inasmuch as it accepted without question the holding by the trial court that the VPG property was owned by the local church free of any trust interest in PCUS. ${ }^{149}$ The Supreme Court vacated the judgment of the Georgia court, ostensibly because the grounds for the latter's decision had not been adequately articulated. ${ }^{150}$ Specifically, the Supreme Court took issue with the Georgia court's reliance on Carnes $v$. Smith ${ }^{151}$ and Presbyterian Church v. Eastern Heights Presbyterian Church ${ }^{152}$ without distinguishing "a significant complicating factor" ${ }^{153}$-the presence of two factions, each claiming to represent the VPG. In contrast to the trial court's characterization, the Supreme Court saw the issue as which of the two competing factions of the formerly united Vineville congregation was actually entitled to the church property. The Georgia court, in deciding that the property vested in the local church as against the general church, had applied neutral principles, but then summarily decided that the majority faction indeed acted for the local church. In the Supreme Court's view, the basis for the state court's determination that the majority, not the minority, represented the local church had not been spelled out. The directions on remand, therefore, were essentially to set forth ex-

147 Jones v. Wolf, 443 U.S. at 604.

148 Id. 603.

149 Id. 600.

150 Id. 610.

151 See note 128 supra \& accompanying text.

152 See note 127 supra \& accompanying text.

153443 U.S. at 606. 
plicit guidelines, consonant with the first amendment, for adjudicating this issue. .154 $^{-}$

By characterizating the crucial issue in the case as the identification of the "true" VPC congregation, the loyal, minority faction sought to persuade the Supreme Court that the case involved not a property dispute but a question "at the core of ecclesiastical concern." 155 The basic premise of its argument was that VPC, as a member of the PGUS hierarchical organization, was subject to all decisions rendered by appropriate PCUS tribunals. Here, the tribunal designated by PCUS had identified and decreed the minority faction to be VPC's "true congregation" as a matter of PGUS's internal church government. As a result, the minority maintained, its authority over the church premises necessarily must be accepted as an incident of this ecclesiastical determination. The minority distinguished the endorsement of neutral principles in Presbyterian Church and Sharpsburg as "simply not analogous to this case," 156 on the ground that those decisions concerned property disputes between a general and a local congregation.

The minority claimed moreover that the Georgia court effectively violated its members' rights under the free exercise clause by redetermining the identity of VPG's "true congregation" and, on the basis of that determination, by awarding control of VPC's property to the majority's representatives. A civil court, the minority argued, may not indirectly overrule a church tribunal's decision concerning an ecclesiastical question by substituting its own judgment under the guise of "neutral principles." Instead, a civil court may resort to the application of neutral principles of law only in the absence of a controlling church-tribunal's determination. Any other reconciliation of the Watson deference principle with the neutral-principles approach, the minority maintained, "would allow both judicial nullification of the parties' agreement to be bound by the church court decision, and wholesale denigration of the private association law which gave rise to that agreement." 157 By characterizing the question at issue as the determination of the "true" Vineville church congregation, the minority was forced to rely on Watson's presumption of implied consent. Indeed, the minority faction conceded that its argument depended

154 Id. 610.

155 Brief for the Petitioners at 15 (quoting Serbian E. Orthodox Diocese v. Milivojevich, 426 U.S. 696, 717 (1976)).

156 Brief for the Petitioners at 33.

157 Id. 30. 
ultimately on the presumption that all member churches of a hierarchical religious society have, "as a matter of simple contract and private association law, bound themselves to adhere to the decisions of those churches' ruling hierarchies." 158

Counsel for the majority faction responded that the Georgia courts did no more than apply the ordinary presumption that, absent some indication to the contrary, a voluntary organization is represented by a majority of its members. They vigorously rejected the minority's attempt to classify the real dispute as ecclesiastical in nature. Although the majority conceded the authority of PCUS to recognize any group it designated as its "true congregation," it firmly denied the general church's power to "adjudicate the property rights [of the local church] in the guise of making 'ecclesiastical' decisions." 169

The decision of the Supreme Court in Jones $v$. Wolf left the Georgia Supreme Court free on remand to adopt explicitly either of the approaches advocated by the respective litigants. On the one hand, Georgia law might provide that the identity of a local church affiliated with a hierarchical religious organization must be determined according to the "laws and regulations" of the hierarchy. If it should choose to do so, the Court hypothesized, "then the First Amendment requires that the Georgia courts give deference to the [hierarchical] commission's determination of that church's identity." 160 On the other hand, the Supreme Court recognized the possibility that Georgia might instead adopt "a presumptive rule of majority representation, defeasible upon a showing that the identity of the local church is to be determined by some other means." 101

The Supreme Court cautioned against the application of an irrebuttable presumption of majority rule, however. It observed that under the neutral-principles approach "any rule of majority representation can always be overcome." ${ }^{162}$ Accordingly, the

158 Id. 29.

159 Brief for Respondents at 15.

160 Jones v. Wolf, 443 U.S. at 609 (footnote omitted). The Court noted, in this regard, that the Georgia Code mandates the vesting of property conveyed to a church in accordance with any limitations set forth in the deed, for use "according to the mode of church government or rules of discipline." Id. See Ga. Code Ann. $\$ \$ 22-5507,22-5508$ (1977). It failed to point out the Georgia Supreme Court's express instruction that these provisions "do not purport to give a general church any rights in local church property other than those rights set forth in the documents of church government." $241 \mathrm{Ga}$. at 211,243 S.E.2d at 863.

161443 U.S. at 607.

$162 I d$. 
Court instructed that, in the event the Georgia Supreme Court did adopt such a rule, it should "specify how, under Georgia law, that presumption may be overcome." ${ }^{163}$ "Because these critical issues of state law remain[ed] undetermined," the Court professed to "express no view as to the ultimate outcome of the controversy if the Georgia Supreme Court adopt[ed] a presumptive rule of majority representation." 164 Nevertheless, the Court did not hesitate to suggest that provisions in the corporate charter or the constitution of the general church, which indicated either "that the identity of the local church is to be established in some other way, or ... that the church property is held in trust for the general church and those who remain loyal to it," 165 would overcome the presumptive rule. ${ }^{160}$ Unlike the deference approach, this kind of rule "would be consistent with both the neutral-principles analysis and the First Amendment." 167

\section{The Nature of the Inquiry Under Neutral Principles: An Attempt at Glarification and Reconciliation}

\section{The Court's Position}

A major source of confusion in the opinion of the Court in Jones $v$. Wolf is the suggestion that judicial inquiry into church

163 Id. 608 n.5.

104 Id. In determining that neither the trial court nor the Supreme Court of Georgia had articulated a presumptive rule of majority representation, the Supreme Court was technically correct. Yet, as the Court itself recognized, the Georgia Code does expressly provide that "[t]he majority of those who adhere to its organization and doctrines represent the church." Id. 608 n.6; see Ga. Code Ann. $\$ 22-5504$ (1977). The Court nevertheless refused to infer that the Georgia courts followed this provision, however, because the Georgia Supreme Court did not even mention it and because the majority faction did not claim at trial any right of possession of the Vineville Church property under this section. 443 U.S. at 608 n.6. But the simple explanation for these failures, as the Georgia Supreme Court pointed out on remand, lies in the fact that the provision in question applies "only to churches having a congregational form of government." 244 Ga. 388, 389, 260 S.E.2d 84, 85 (1979). And at the trial stage, at least, both the court and the litigants apparently perceived the crux of the dispute to be between PCUS and VPC, not between the majority and minority factions of VPC. Thus, it should have come as no surprise when on remand the Georgia Supreme Court expressly adopted the presumptive rule of majority representation and unanimously reinstated its affirmance of the judgment of the trial court. Id.

165443 U.S. at 608.

166 In conformance with the Supreme Court's instructions, the Georgia court adopted a rule of majority representation and specified that it could be overcome under neutral principles by indication of a contrary intention in neutral statutes, corporate charters, relevant deeds, and organizational constitutions. But the court's review of those sources in this particular case disclosed no evidence rebutting the presumption of majority representation, at least with respect to the use and control of the church premises. See note 164 supra.

167443 U.S. at 607. 
polity is now constitutionally prohibited. At least on the surface, the Court appears to assume that the first amendment forbids consideration by civil courts of church constitutions, charters, and other relevant documents for evidence pertaining to the form of government voluntarily adopted by the churches upon their affiliation. Indeed, one of the advantages claimed for the neutral-principles approach is that it "obviates entirely the need for an analysis or examination of ecclesiastical polity or doctrine in settling church property disputes." 168 For all that, it is nonetheless difficult to reconcile this position with the contrary prescription, implicit in the Court's opinion, that civil courts should examine church documents establishing a church's polity in order to ascertain "what religious body" the parties intended to have "determine the ownership in the event of a schism or doctrinal controversy." 169 On close examination, no meaningful distinction can be drawn between the process of determining whether the parties meant to create a trust in favor of the general church and that of deciding in whom the parties intended to place ultimate authority over the church property.

The apparent discrepancy may be traced to a subtle yet crucial misapprehension of the constitutional parameters fixed in Presbyterian Church, ${ }^{170}$ Sharpsburg, ${ }^{171}$ and Serbian. ${ }^{172}$ All three decisions recognized the danger that adjudication of church-property disputes might entangle civil courts in "quintessentially religious controversies." 173 For this reason, the Court held in Presbyterian Church that the first amendment "commands civil courts to decide church property disputes without resolving underlying controversies over religious doctrine." 174 Similarly, Sharpsburg's approval of judicial inquiry into and reliance on provisions in religious documents was expressly conditioned on the fact that the state "court's resolution of the dispute involved no inquiry into religious doc-

$1681 d .605$.

$109 \mathrm{Id} .603$.

170 See notes $71-76$ supra \& accompanying test.

171 See notes 79-86 supra \& accompanying text.

172 See notes 87-110 supra \& accompanying text.

173 Serbian E. Orthodox Diocese v. Milivojevich, 426 U.S. 696, 720 (1976). "First Amendment values are plainly jeopardized when church property litigation is made to turn on the resolution by civil courts of controversies over religious doctrine or practice." Id. 709-10 (quoting Presbyterian Church v. Mary Elizabeth Blue Hull Memorial Presbyterian Church, 393 U.S. 440, 449 (1969)). 
trine." 175 In Serbian, the Court reaffirmed the prohibition against judicial intrusion into purely ecclesiastical matters and emphasized that resolution of "quintessentially religious controversies" must be left to the "church judicatory in which authority to make the decision resides." 176

Despite the Court's intimation to the contrary in Jones $v$. Wolf, however, Serbian neither foreclosed civil-court inquiry into the form of polity adopted by associated churches nor compelled judicial deference to the resolution of an altercation regarding church polity by a tribunal of a hierarchical church. Far from requiring civil courts to refrain from examining church documents for evidence of the polity adopted by members of a religious association, the Court's decision in Serbian itself was based on an examination of provisions in the respective church documents. ${ }^{177}$ As in Sharpsburg, the church charters and constitutions, the deeds to the disputed property, and the relevant state statutes were canvassed specifically "for information about the basic polity" 178 adopted by the competing religious groups. On the basis of this investigation, the Court concluded that ultimate authority to prescribe the use of the church property was, in Sharpsburg, with the local congregation and, in Serbian, with the hierarchical church organization. In neither case, however, did the judicial inquiry into church polity involve an impermissible entanglement in religious matters. What the Court held impermissible was not the ascertainment of polity by means of a careful examination of church documents, but rather, as the dissent in Jones $v$. Wolf noted, "the state court's further inquiry into the faithfulness of the church hierarchy's decisions to the detailed provisions of church law." 170 Indeed, it was precisely because the polity previously adopted by the quarreling factions committed the matters in dispute to the exclusive province of the mother-church organization that the Serbian Court refused to permit the state court to substitute its interpretation of church law for that of the hierarchical tribunal in which authority to make the interpretation was found.

175 Maryland \& Va. Eldership v. Church of God at Sharpsburg, Inc., 396 U.S. 367, 368 (1970); see Jones v. Wolf, 443 U.S. at 612 n.I (Powell, J., dissenting).

176426 U.S. at 720 .

177 See note 107 supra \& accompanying text.

178 Jones v. Wolf, 443 U.S. at 612 n.I (Powell, J., dissenting).

179 Id. 620 n.8 (Powell, J., dissenting) (citing Serbian E. Orthodox Diocese v. Milivojevich, 426 U.S. at $712-13,718,721-23$; id. 725 (White, J., concurring)). 
If Jones $v$. Wolf does stand for the proposition that judicial intervention in church-property disputes may no longer entail an investigation into church polity, then it certainly represents a significant and possibly unjustifiable digression from prior decisions. In our view, however, the Court's opinion is susceptible to a more considered and sympathetic interpretation, one that construes the neutral-principles approach somewhat less restrictively. Under this interpretation, courts addressing property disputes may consider the polity adopted by church groups so long as they refrain from resolving the conflict on the basis of religious doctrine or practice. After all, judicial examination of church charters and constitutions in order to determine whether there is any basis for finding a trust of church property does constitute an investigation into church polity. The characteristics of such an inquiry, however, must be carefully defined. Civil courts are to look to the form of government manifested in church documents only to locate the body in which the religious associations intended to place ultimate authority over church property. If that polity indicates "what is to happen to church property in the event of a particular contingency, or what religious body [is to] determine the ownership in the event of a schism or doctrinal controversy," 180 civil courts will be bound by the Court's admonition "to give effect to the result indicated by the parties, provided it is embodied in some legally cognizable form." 181

Assuming this analysis to be correct, all nine members of the Court basically agree on the proper aim of judicial inquiry into church-property disputes under "neutral principles of law." Courts should examine all legally cognizable evidence for the purpose of determining in whom, at the time of their association, the competing groups intended to place ultimate authority over the church property in dispute. The main difference, then, between the conflicting positions set forth by the majority and the dissent in Jones v. Wolf centers not on the ultimate goal of judicial inquiry, but rather on the scope of "legally cognizable evidence" of church intent regarding control of its property. It is necessary, therefore, to explore the dissent's view of constitutionally permissible adjudication in an attempt to reconcile it with the Court's conception of neutral principles of law.

180 Jones v. Wolf, 443 U.S. at 603.

181 Id. 606. 
2. The Dissent's View, and a Response

Labeling it "newly defined" 182 and a "depart[ure] from longestablished precedents," ${ }^{183}$ the dissent, speaking through Mr. Justice Powell, took strong exception to the Court's conception of "neutral principles of law." The focus of the dissent's criticism was the Court's directive that civil tribunals adopting this approach must scrutinize church documents in secular terms for evidence of a trust, without reliance on religious precepts or doctrine. Inasmuch as church charters and constitutions "tend to be drawn in terms of religious precepts," 184 the dissent countered, "[a]ttempting to read them 'in purely secular terms' is more likely to promote confusion than understanding." ${ }^{185}$ The dissent also contended that the Court's approach would effectively preclude certain types of evidence from judicial consideration altogether. In its view, confining civil courts exclusively to reliance on evidence cognizable in secular terms would deny to them relevant evidence pertainingto the church's form of government whenever that polity "has not been expressed in specific statements referring to the property of a church." 186

The dissent may have been somewhat misled by Mr. Justice Blackmun's insistence that, in applying neutral principles of law, courts should rely not on religious precepts but on "objective, well-established concepts of trust and property law." 187 In order to ascertain whether a local congregation intended to relinquish control over its property upon association with a hierarchical church, he stated, courts are to examine numerous sources, including religious documents, "for language of trust in favor of the general church, ... [and should] take special care to scrutinize the document in purely secular terms." 188 The dissent read these instructions as prohibiting consideration of any evidence of the litigants' intentions with respect to church property unless the parties have reached an express understanding regarding the property. Close examination of the Court's opinion reveals little justification, however, for reading such a limitation into the neutral-principles approach. The dissent's criticisms overlook the sophistication with

182 Id. 610 (Powell, J., dissenting).

183 Id. 611 (Powell, J., dissenting).

184 Id. 612 (Powell, J., dissenting).

$185 \mathrm{Id}$.

186 Id. 612-13 (Powell, J., dissenting).

187 Id. 603.

188 Id. 604. 
which established principles of trust law can be employed to ascertain the existence of an implied trust.

What apparently concerned the dissent was the possibility that a particular congregation might submit itself to the authority of a hierarchical-church organization, without expressly subordinating control over church property. But associated churches need not explicitly refer to property to indicate the intention that the general church is to have unfettered authority over the local church in all matters, including control over property. So long as the nature of the relationship may be judicially inferred without entanglement in religious doctrine, there is no reason for a court not to enforce the terms of that relationship.

The Court's elaboration upon "neutral principles" in Jones v. Wolf, in effect, represents no more than an attempt "to constrain the grounds on which courts act, instructing them above all to avoid modes of decision that involve resolving by law issues of religious faith and doctrine." 189 Short of such an intrusion, however, courts are entitled to adjudicate church disputes over property "in accord with the desires" 190 of the religious association as framed prior to the dispute, at least to the extent that those desires are evident. When a written document contains an express provision respecting control over the property, this task will not prove difficult. In the absence of such an explicit guide, however, courts adopting neutral principles still must attempt to discern the parties' original intentions respecting the control of church property and to enforce that understanding. Evidence that a local congregation intended, upon affiliating with another religious organization, to cede its autonomy to that group certainly would support a finding that the parties also contemplated a trust of the local church's property in favor of the general church, despite the absence of any specific statement referring to the property.

Neither the majority nor the dissent in Jones $v$. Wolf seriously contended that judicial examination of religious documents is constitutionally prohibited. As contrasted with the secular inquiry advocated by the majority, however, the dissent appeared to suggest that courts should rely on religious precepts in the course of interpreting and evaluating such documents. ${ }^{191}$ Yet to the extent that courts do so, they might abridge the distinct constitutional rule-clearly enunciated in Presbyterian Church and re-

189 L. TruBe, supra note $9, \S 14-13$, at 882 .

190 Jones v. Wolf, 443 U.S. at 604.

101 Id. 611-12 (Powell, J., dissenting). 
peatedly affirmed in Sharpsburg, Serbian, and now Jones v. Wolf -that civil adjudication of church-property disputes must avoid modes of decision that require inquiry into ecclesiastical matters of faith and doctrine. Thus, the dissent's claim that attempting to read church documents in secular rather than religious terms is "more likely to promote confusion than understanding," 192 is questionable. Although civil courts have an expertise in the tasks of interpreting documents and discovering the intentions of parties to contracts, that expertise presumably does not extend to ecclesiastical matters. ${ }^{193}$ By refusing to undertake an inquiry into such questions, the Court in effect is heeding Professor Chafee's advice against rushing into the "dismal swamp" of obscure church rules and doctrines. ${ }^{194}$ As to these matters, the Court appears to be saying, only members of the religious association can claim to speak with competence.

Nevertheless, the dissent's criticisms do highlight the important insight that judicial inquiry into either a church's polity or its intentions respecting church property, by its very nature, cannot possibly be "purely secular." As Professor Kauper recognized, "civil courts in identifying a church's polity for legal purposes are necessarily at the same time passing on important ecclesiastical questions respecting the nature of the church and its authority." 195 No less is involved when a court attempts to determine whether the members of a religious society intended to create a trust. For whether a court investigates religious documents to ascertain in which body the polity of the religious society has placed ultimate authority over church property or to discover whether there is any basis for finding a trust of that property in favor of a body other than the formal titleholder, "it is resolving a legal issue by reference to a standard that requires a judicial interpretation of ecclesiastical sources." 196

The critical distinction that must be drawn, however, lies between a strictly secular inquiry into these sources, designed solely to accord legal effect to the private arrangements of a re-

192 Id. 612 (Powell, J., dissenting).

193 See Developments in the Law-Judicial Control of Actions in Private Associations, 76 Harv. L. REv. 983, 991-92 (1963), and cases cited therein raising questions such as the proper interpretation of the doctrine of "plenary inspiration" and whether "goats are sheep in disobedience." Judicial review of the decisions of a church tribunal on these issues likely would constitute "an appeal from a learned body to an unlearned body." Chafee, The Internal Affairs of Associations Not for Profit, 43 Harv. L. REv. 993, 1024 (1930).

194 Chafee, supra note 193, at 1024.

195 Kauper, supra note 9, at 371. $196 \mathrm{Id}$. 
ligious association respecting property, and a more extensive reading of these sources in religious terms that would require a judicial evaluation of matters of ecclesiastical faith and doctrine. Recognition of this distinction, and its role in delimiting neutral-principles analysis, is the first step toward harmonizing the Court's endorsement of neutral principles and the dissent's concern that this approach will "interfere with the free exercise of religion in accordance with church polity and doctrine." 197

\section{Application of Neutral Principles in Jones v. Wolf}

The four dissenting Justices did not see any reason to apply neutral principles in Jones $v$. Wolf. Perceiving no occasion for further examination of the law of Georgia, they instead would have reversed and directed the Georgia court to enter judgment for the minority faction.

The dissent recognized that the schism in the Vineville Church stemmed from disagreements regarding doctrine and practice. Under the laws and regulations of PCUS, the hierarchy retained general and unqualified authority to resolve these questions for the membership of PCUS. Similarly, power to review the discipline of church members also resided in appropriate tribunals of the hierarchy. These tribunals had resolved the issues in controversy by purporting to grant legal ownership of VPG property to the minority faction of the congregation that had remained loyal to PCUS. By awarding control of the property to the dissident majority, in the face of a decision to the contrary by an authoritative PGUS tribunal, the Georgia court, according to the dissent, had reversed the doctrinal decision of the church tribunal. For this reason, the dissent refused to accept the trial court's determination that the local congregation at no time surrendered control over its property to the general church. In its view, the Court's endorsement of a secular inquiry into the intentions of the parties simply could not "be justified on the ground that it "free[s] civil courts completely from entanglement in questions of religious doctrine, polity, and practice." 198 For, according to the dissent, "indirect interference" by civil courts in the "resolution of religious disputes within the church," no less than direct decisions regarding questions of doctrine and practice, is "proscribed by the First Amendment." 199

197 Jones v. Wolf, 443 U.S. at 616 (Powell, J., dissenting).

198 Id. 613 (Powell, J., dissenting) (quoting id. 603).

199 Id. (Powell, J., dissenting). 
This apparent equation of questions of doctrine and practice with questions of control over church property, in our view, constitutes a flaw in the dissent's analysis. Inasmuch as the first amendment prohibits judicial inquiry into ecclesiastical matters of doctrine and practice, resolution of such issues necessarily must be made, if at all, within the structure of church government. Whether a civil court may inquire into church-property disputes, however, depends entirely on whether the parties committed those questions to the exclusive province of a particular religious society. And this issue is not an exclusively ecclesiastical issue but rather one that properly may be submitted to a civil court for resolution.

The dissent apparently assumed that the membership of VPC, by committing final review of decisions respecting doctrine, practice, and church discipline to the hierarchy, ${ }^{200}$ in effect did consent to the authority of PGUS over VPG in all matters, including property control. But the question whether VPG members actually submitted themselves to PGUS's final authority in doctrinal matters is distinct from the question whether VPG meant to give to PCUS the authority either to control the church property or to identify VPC and its representatives for purposes of property ownership. Indeed, the power to constitute the titleholder would be equivalent to the right of control over church property. And whether the issue presented in Jones $v$. Wolf is described as a dispute over the ownership of VPC's property or over who represents VPG for purposes of property ownership, no constitutional considerations bar civil courts from determining for themselves whether the local church, upon its affiliation with a hierarchical organization, meant to confer on the latter body the authority claimed.

It was just such an inquiry, through an examination of the relevant documents, that convinced both Georgia courts that PCUS "had no authority by resolution to constitute [the minority faction of VPC] as the true congregation for the purpose of creating a trust relationship with respect to the church property of VPC

200 The local church was said to consist of "all the communing members of the active roll" of the church, which in turn was composed "of those admitted to the Lord's table who are active in the church's life and work." Book of CHurce Order of the Presbytertan Churce $\$ \$ 6-2,8-7$; App. 35, 38 (1972). Local church representatives were given the power "to suspend or exclude from the Lord's Supper those found delinquent, according to the rules of Discipline." Id. $\$ 15-6(2)$; App. 51. Such decisions were subject to "the review and control" of the hierarchy as part of its general authority to "order whatever pertains to the spiritual welfare of the churches under its care." Id. $\$ \$ 14-5,16-7(19)$; App. 49, 56. See Jones v. Wolf, 443 U.S. at 609 n.7. 
when none previously existed." 201 The objection that the Georgia courts thereby imposed their own form of government and procedure in determining who constitutes the church is simply a mischaracterization of the outcome. Those courts did not substitute their own resolution of a religious question for that of an ecclesiastical tribunal; rather, they determined that the identity of VPC, at least for the purpose of property ownership, was not a matter of the internal affairs of PCUS because VPC neither intended nor consented to confer on PGUS the authority to make that determination. And whether a particular question is a matter of internal church affairs, which may not be intruded upon by a civil court, depends entirely on whether the parties consented, either expressly or by implication, to have the issue resolved within the structure of church government.

A local church may, of course, affliate with a hierarchically structured religious society on terms that would effectively place the property of the local church under the control and disposition of the hierarchical body. If a local church has in fact agreed to submit property disputes to specially established church tribunals for resolution, civil courts must then accept such determinations as conclusive, at least in the absence of fraud or collusion. But when a local church challenges the hierarchical organization's authority to dispose of its property, no Supreme Court decision mandates that a civil court must defer automatically to an ecclesiastical tribunal's ruling on that question. Nor has any decision of the Court conditioned the application of neutral principles upon the absence of a ruling by an ecclesiastical tribunal. Despite a hierarchical tribunal's determination, a civil court may still inquire into the nature of the relationship between the local congregation and the general church in order to determine whether the former in fact consented to the latter's authority to make that particular determination.

The Court's endorsement of judicial inquiry into the intentions of the parties under the rubric of neutral principles thus represents a significant doctrinal development. It presumes that more than a mere association between the parties is necessary to accord one party rights over the other's property. A church may choose to affiliate with a separate hierarchical religious organization for certain purposes, consenting to the latter's "authority" to resolve questions of doctrine and practice for that association, and at the same time retain its autonomy and its right to prescribe the use

201 No. 45787 D-2 (Bibb Super. Ct., filed Sept. 30, 1977). 
and control of its property. ${ }^{202}$ When a church affiliates on these terms, the members remain free, in the event of a disagreement over doctrine or practice, simply to sever the local church's relation with the hierarchical organization and withdraw itself and its property from that association, regardless of any purported adjudication of this question by the hierarchy. Thus, even if VPC on becoming a member unit of PGUS consented to that body's authority to resolve questions of faith and practice for the entire membership of PCUS, that consent alone would not necessarily constitute consent on the part of VPC either to create a trust of its property in favor of the general church or to cede to PCUS the autonomous control over its affairs, by becoming inseparably integrated into and completely subordinated to that organization.

\section{The Effect of Jones $v$. Wolf: Constitutional Concerns}

Jones $v$. Wolf makes clear that states are constitutionally entitled to adopt "neutral principles of law" as a means of adjudicating church-property disputes. Under this approach, the aim of judicial inquiry is to ascertain the body in which the parties mutually consented to place ultimate authority over the property, so as to decide the controversy in accord with the intentions of the parties. Provided the churches in association have embodied their intentions in some legally cognizable form, "civil courts will be bound to give effect to the result indicated by the parties." 203

202 This argument is supported by the amicus curiae brief submitted by the Presbyterian Church in America. This hierarchical organization specifically maintains the autonomy of local congregational control over church property. The Constitution of the Presbyterian Church in America reads: "All particular churches shall be entitled to hold, own and enjoy their own local properties, without any right of reversion whatsoever to any Presbytery, General Assembly, or any other courts hereafter created, trustees or other officers of such courts." Presbytkerdan Church In AMmertaA, Book of Church Order \$26-9, quoted in Brief Amicus Curiae on Behalf of Respondents Urging Denial of Petition for Writ of Certiorari at 4 .

This provision may profitably be compared with the Constitution of the United Presbyterian Church in the United States of America:

Whenever hereafter a particular church is formally dissolved by the presbytery, or has become extinct by reason of the dispersal of its members, the abandonment of its work, or other cause, such property as it may have ... shall be held ... and applied for such uses ... as the presbytery may direct, limit, and appoint, or such property may be sold or disposed of as the presbytery may direct, in conformance of the Constitution of The United Presbyterian Church in the United States of America.

Untted Presbytertan Church in the United States of America, II Book of ORDER \$ 62.11 (1967).

203 Jones v. Wolf, 443 U.S. at 606. 
Despite its strong endorsement of "neutral principles of law," the Supreme Court indicated nonetheless in its instructions on remand that this approach to the resolution of church-property disputes represents merely an optional, not a required, mode of decision. Apparently, civil courts are free, alternatively, to avoid an inquiry into the parties' actual intent and to decide churchproperty disputes instead on the basis of the Watson $v$. Jones fiction of an implied consent by associated churches to the authority of the general church. ${ }^{204}$ As the Court in Jones $v$. Wolf appeared to recognize, this implied-consent principle in effect constitutes "a rule of compulsory deference to religious authority in resolving church disputes." 205 Even when the authority over the local church's property is disputed, it seems, civil courts using this approach must defer to and enforce the decisions of the highest body within the hierarchy.

\section{A. The Continuing Force of Watson v. Jones}

Justice Miller's statement of the implied-consent principle in Watson $v$. Jones ${ }^{206}$ was merely dictum and, although sometimes cited, it has never been the subject of a Supreme Court holding. The doctrine of implied consent was not necessary to the Court's decision in Watson because it was undisputed that the local church had submitted its property to the general church's control. Nevertheless, a number of state courts have felt bound by Watson's prescription of implied consent, apparently out of a desire to avoid judicial intrusion into the affairs of religious associations. ${ }^{207}$

Mills $v$. Baldwin, ${ }^{208}$ a recent decision of the Florida Supreme Court, presents an excellent case in point. Under circumstances virtually identical to those at issue in Jones $v$. Wolf, the Florida court reached a result opposite to that arrived at by the Georgia courts. The "true issue" 209 in Mills, according to the Florida court,

204 In Watson the Court simply assumed that local church groups associated with hierarchical religious organizations thereby consent to be governed exclusively, and without any interference whatsoever by the state, by the hierarchy's authorities. Watson v. Jones, 80 U.S. (13 Wall.) 679, 729 (1871). See note 49 supra \& accompanying text.

205 Jones v. Wolf, 443 U.S. at 605.

20680 U.S. (13 Wall.) 679, 729 (1871). See notes 49 \& 204 supra \& accompanying text.

207 See note 115 supra.

208344 So. 2d 259 (Fla. App. 1977), rev'd, 362 So. 2d 2 (Fla. 1978), vacated and remanded, 443 U.S. 914 (1979). The state court decision was vacated and remanded by the Supreme Court for further consideration in light of Jones v. Wolf.

209362 So. $2 d$ at 7. 
was which of two factions represented the local church. The court found that "authority to identify the local church [resided] in the hierarchy" 210 solely because the local congregation was associated with the hierarchical organization. To the Florida Supreme Court, the finding by the intermediate appellate court that "no understanding affecting property" ever existed between the two religious bodies "ignored the character of the commitment" 211 made by the local church when it affiliated with the general church. "That commitment," in the view of the Florida Supreme Court, "was total and without reservation": ${ }^{212}$

In the absence of a specific understanding or agreement preserving a separate entity and expressing an intention to withhold its property we think it must be presumed that by voluntarily merging itself as an organ of the larger body, it intended to dedicate its all to the purposes of that body. ${ }^{213}$

Any other approach, the Florida court concluded, would "depart from the well-established rule of Watson $v$. Jones." 214

Other state courts, like Georgia's, have rejected such a presumption of consent in favor of an inquiry, under "neutral principles of law," into the nature of the association between the contesting religious groups. ${ }^{215}$ Desirous of accomplishing Watson's professed goal of providing protection to religious groups equivalent to that enjoyed by other voluntary associations, these courts have attempted to adjudicate such controversies by discerning and enforcing the actual intentions of the parties.

As a practical matter, therefore, Jones $v$. Wolf is likely to promote greater uncertainty and confusion among state courts concerning the permissible forms and limits of judicial intervention in church-property disputes. By tempering its strong endorsement of "neutral principles of law" with an apparent, albeit less enthusiastic, approval of Watson's fiction of implied consent, the

210344 So. $2 d$ at 268 (Smith, J., dissenting). The Florida Supreme Court explicitly "subscribe[d] to the reasoning and conclusion of Judge Smith's dissent below" and claimed that "it would be of little benefit to restate what was so ably put by him." 362 So. $2 \mathrm{~d}$ at 5 .

211344 So. $2 \mathrm{~d}$ at 269 (Smith, J., dissenting).

$212 I d$.

213 Id. (quoting Reformed Bethanian Church v. Ochsner, 72 S.D. 150, 159-60, 31 N.W.2d 249, 254 (1948) (emphasis added)).

214344 So. $2 d$ at 269.

215 See note 116 supra. 
Supreme Court offered limited guidance to civil courts deliberating between these two approaches. "Courts trying to be fair and unbiased," as one student commented after the Presbyterian Church decision, will continue to "face great perplexity in trying to decide what the Supreme Court really meant and which of the available rules they should apply." 216

Moreover, the inclusion of contradictory doctrines in Jones v. Wolf may allow certain state courts the opportunity "to choose arbitrarily between the Watson rule and neutral principles with apparent justification depending upon which litigant or which rule they prefer." 217 State courts willing to inject their own preferences regarding church polity often will be able, in the absence of an express provision regarding church property, to adopt the presumption reflecting their own predilections. Furthermore, the Court's opinion appears to dash any hope that may have existed for a definitive and uniform rule of decision. National and local churches alike continue to face the prospect of conflicting results depending upon the state of adjudication.

The most serious consequence of the Court's opinion lies, however, not in its effects upon state law but, as the dissent suggests, in the fact that "important issues of federal constitutional law thus are left to the state courts for their decision." 218 For churches, no less than individuals, may "stake out some very elementary and basic claims to freedom under the First Amendment." 219 By failing to address the first amendment implications of the doctrine of implied consent, the Court in Jones $v$. Wolf left the state courts to trace a constitutional course at least poorly mapped, if not, as the dissent claims, "totally uncharted." 220

\section{B. The Constitutional Necessity of Neutral Principles}

The Supreme Court's choice in Watson v. Jones between judicial intervention or deference to the church tribunal depended on an inquiry into church polity. Mr. Justice Miller intended that churches should stand before the law precisely as would other forms of voluntary association, subject in the same manner and to the same extent to civil authority.221 The Court thus attempted to

216 The Supreme Court, 1968 Term, 83 HARv. L. REv. 7, 133 (1969).

217 Id.

218 Jones v. Wolf, 443 U.S. at 616 (Powell, J., dissenting).

219 Kauper, supra note 9, at 376.

220 Jones v. Wolf, 443 U.S. at 616 (Powell, J., dissenting).

221 See note 48 supra \& accompanying text. See generally Chafee, supra note 193; Jaffe, Law Making by Private Groups, 51 HaRv. L. Rev. 201 (1937); De- 
promote the policies embodied in the religion clauses by strictly protecting the principle of freedom of association. Such freedom not only permits but requires that parties be free to determine the limits and purposes of their relationship. Under this approach, whatever authority a hierarchical organization may have over associated local churches is derived solely from the local churches' consent.

If a general church's hierarchical authority over a local church and its property is undisputed, as it was in Watson $v$. Jones, civil courts must settle the conflict by discerning and enforcing the decision of the highest church authority. Kedroff v. Saint Nicholas Cathedral ${ }^{222}$ and Serbian Eastern Orthodox Diocese v. Milivojevich, ${ }^{223}$ for example, both represent applications of Watson's deference principle. Judicial deference to the decision reached by the appropriate hierarchical tribunal was premised in each case on the fact of the local church's consent, either express or implicit, to be governed by the hierarchy's resolution of the matter. Inasmuch as such deference merely reflected the local church's intention and consent to adhere to the determinations reached by the ruling hierarchy, it constituted a "neutral principle of law." Application of the deference approach presupposes, however, that the religious body with ultimate authority to prescribe the use of the church property can be identified.

In certain circumstances, the task of ascertaining the intention of associated church groups respecting ownership and control over church property will be far from easy. Yet, the prospect of diffculty in discovering the intentions of the parties cannot justify judicial refusal to resolve controversies between churches over property or contracts. As Mr. Justice Miller noted in Watson, religious organizations, like all voluntary associations, "are equally under the protection of the law, and the actions of their members subject to [the same] restraints." 224 Indeed, refusal to adjudicate a dispute over property rights or contractual obligations simply because the litigants are religious organizations "smacks of a denial of equal protection as well as a violation of first amendment rights." 225 When a local church claims to have surrendered neither its autonomy nor its right to use church property, yet alleges usurpation

velopments in the Law-Judicial Control of Actions of Private Associations, 76 Harv. L. REv. 983 (1963).

222344 U.S. 94 (1952). See notes 64-69 supra \& accompanying text.

223426 U.S. 696 (1976). See notes 87-110 supra \& accompanying text.

224 Watson v. Jones, 80 U.S. (13 Wall.) 679, 714 (1871).

225 Casad, supra note 48 , at 432 . 
by the hierarchy, it must have recourse to an impartial body to resolve its claims. The presumption that, by entering into an association with the hierarchical organization, a local church thereby gives up to the hierarchy autonomous control over its property, in effect begs this central question. As a result, the rule of compulsory deference, in conjunction with implied consent, denies to local churches the same protection of law afforded to other voluntary associations.

Judicial adherence to Watson's prescription of implied consent has been grounded in a desire to further religious liberty through the separation of church and state. Constrained by the misleading metaphor of a "wall of separation" in church-state relations, some civil courts, reluctant to participate in disputes involving churches, have in professed compliance with the dictates of the religion clauses avoided inquiry into the nature of the parties' actual agreement. But the issue of judicial intervention into church disputes is not one of defining separate spheres within which churches and states respectively should operate. Rather, it is to develop standards that will assure all religious groups the equality of treatment that the first amendment requires.

Tying control of a local church to a hierarchical organization, regardless whether the local church in fact has relinquished control, effectively limits the ability of local church congregations to establish the terms of their association with more general church organizations. Moreover, local churches desirous of associating with a hierarchical organization for purposes of religious worship may be inhibited from such association by a well-founded fear of losing their property. The assumption that a local church has consented, at least in the absence of an express provision to the contrary, to another religious group's authority over its property imposes additional legal requirements on local churches that may constrain their right to associate with other religious groups. In this manner, adherence by state courts to the implied-consent theory may constitute a violation of the free exercise clause.

At the same time, by encouraging and supporting a hierarchical form of church polity over other alternative forms, adoption of Watson's fiction of implied consent would appear to constitute a judicial establishment of religion. No less than tangible state financial assistance, judicial support of one institutional form of church polity over another is prohibited by the first amendment. ${ }^{226}$ In our view, local churches that lose control over their property, on 
the basis of a judicial presumption that they relinquished control to a hierarchical society, may claim that such judicial action not only violates their rights under the free exercise provision, but also constitutes a breach of the establishment clause. When faced with two competing religious groups, each of which claims the right to control certain property, civil courts must not be allowed to presume in favor of one side or the other; rather, they should be required to determine which religious society in fact retains legal ownership of the property. The only approach that is both consistent with the strictures of the free exercise and the establishment clauses, as well as with the premise-apparently accepted by all members of the Court in Jones $v$. Wolf-that judicial resolution of church-property disputes should reflect the intentions of the parties, is one that remains strictly neutral between the parties.

\section{Conclusion}

The application of "neutral principles of law" respects the right of a church body to affiliate for some reasons, agreeing to abide by certain conditions, yet refusing to become associated for other purposes. Moreover, it recognizes that different kinds of affiliations exist among religious groups according to the institutional arrangements agreed upon by their members. Unlike the impliedconsent approach, "neutral principles of law" embody no preference among these various organizational possibilities, nor do they impose on any church particular legal requirements that might inhibit the formation of religious associations. And, because neutral principles are not result-oriented, the outcome of a church-property dispute is not foreordained. ${ }^{227}$

Neutral-principles analysis is premised on the fact that, prior to the association between the competing churches, control of the property rested indisputably with one of the parties. From that premise, a court then should proceed to examine all relevant evidence for indications whether this control has "ever been surrendered or lost, either by cession of the property to another group. or by relinquishment of control over the property by other legally cognizable means." 228 The only restriction on this inquiry is that courts confine themselves within the strictures of the religion clauses by avoiding the interpretation or evaluation of matters of ecclesiastical doctrine or practice. 
Application of neutral principles will not prevent courts from finding the creation of a trust of church property in favor of a religious organization when the circumstances dictate. ${ }^{229}$ But neither will this approach presume the existence of such a trust in the absence of an indication that the local church intended, either expressly or by implication, to submit its property to the control of a separate religious body. Judicial adherence to this mode of decision, therefore, would not only recognize the freedom of churches to determine the limits and purposes of their association, but would also encourage them to comply with their obligation to "structure relationships involving church property so as not to require the civil courts to resolve ecclesiastical questions." 230 At any time before a church dispute erupts, the parties can ensure, if they so choose, that the hierarchical body or a faction loyal to it will retain the church property, simply by expressing that intention clearly. Thus, as the Court in Jones $v$. Wolf concluded, "the promise of nonentanglement and neutrality inherent in the neutral-principles approach more than compensates for what will be occasional problems in application." ${ }^{231}$ What is more important, the resulting resolution of church disputes by this method would avoid using religion "as a standard for action or inaction ... either to confer a benefit or to impose a burden" ${ }^{232}$ and thus assure all church groups the equality of treatment that the first amendment requires.

229 In Carnes v. Smith, 236 Ga. 30, 222 S.E.2d 322, cert. denied, 429 U.S. 868 (1976), for example, the case in which the Georgia Supreme Court first endorsed the application of neutral principles, the local church's claim of autonomy was rejected on the basis of provisions dealing with church property and control in the United Methodist Church's Discipline. These provisions clearly showed the parties' intention that the local church should hold the property in the general church's behalf. Subsequently, in Crumbley v. Solomon, 243 Ga. 343, 254 S.E.2d 330 (1979), the Georgia Supreme Court again found a trust of local church property for the benefit of the general church on the basis of the Disciplinary Rules of the Holiness Baptist Association, which provided in part that the Association "shall hold all church property, regardless if all members vote to change the church to some other faith.” $243 \mathrm{Ga}$. at 344,254 S.E.2d at 332 . Because the local church had participated in making the rule and did not contest its validity for thirty years, the Georgia Supreme Court held that it could not "now deny the existence of a trust for the benefit of the general church." $243 \mathrm{Ga}$. at 345,254 S.E.2d at 332. 230 Presbyterian Church v. Mary Elizabeth Blue Hull Memorial Presbyterian Church, 393 U.S. 440, 449 (1969), quoted in Jones v. Wolf, 443 U.S. at 604. 231 Jones v. Wolf, 443 U.S. at 604.

232 Kurland, supra note 31 , at 24 (quoting P. KunLaNd, ReLigion aNd the LAW $112(1962))$. 